„Analecta Cracoviensia” 52 (2020), s. 89-129

DOI: https://doi.org/10.15633/acr.4047

Beata Stypułkowska

https://orcid.org/oooo-0002-8978-7190

Wyższy Instytut Teologiczny w Częstochowie

\title{
Formacja teologiczna w ordo virginum
}

Niniejszy artykuł jest szóstym z kolei tekstem na temat indywidualnych form życia konsekrowanego ${ }^{1}$. Dotyczy formacji teologicznej w stanie dziewic, czyli ordo virginum $\mathrm{z}$ uwzględnieniem procesu rozeznania powołania $\mathrm{i}$ formacji przed konsekracją oraz formacji po konsekracji. Na temat formacji konsekrowanych wypowiedział się bp Jacek Kiciński $\mathrm{CMF}^{2}$. W niniejszym artykule będą odwołania do tego wystąpienia. Instrukcja na temat ordo virginum zatytułowana Ecclesiae Sponsae Imago podaje konkretne wytyczne dotyczące formacji konsekrowanych i wyróżnia jej dwa etapy: formację początkową z właściwymi sobie fazami oraz formację stałą ${ }^{3}$ Z instrukcji tej przejęto główne wskazania, wzbogacając je wnioskami wysnutymi z kodeksu prawa kanonicznego

\footnotetext{
Zob. B. Stypułkowska, Indywidualne formy życia konsekrowanego w kontekście Roku życia konsekrowanego, „Częstochowskie Studia Teologiczne” 43 (2015), s. 117-145; B. Stypułkowska, Biblijna katecheza o miłosierdziu skierowana do dziewic konsekrowanych. Przyczynek do formacji stałej, w: Oblicza miłosierdzia w Biblii, red. J. Jaromin, Wrocław 2016, s. 97-122; B. Stypułkowska, Perspektywy dla dziewic konsekrowanych żyjących w świecie wynikające z duchowości monastycznej, "Analecta Cracoviensia" 48 (2016), s. 195-222; B. Stypułkowska, Rady ewangeliczne w życiu dziewicy konsekrowanej, „Annales Canonici” 14 (2018) II, s. 291-321; B. Stypułkowska, Pustelnicy jako przedstawiciele indywidualnej formy życia konsekrowanego, „Analecta Cracoviensia” 50 (2018), s. $125-160$.

${ }^{2}$ Miało to miejsce podczas spotkania Podkomisji KEP ds. Indywidualnych Form Życia Konsekrowanego [dalej: IFŻK], Centrum Promocji IFŻK oraz diecezjalnych referentów ds. IFŻK w dniu 21 kwietnia 2018 roku. Por. J. Kiciński CMF, Formacja początkowa i stała $w$ dziewictwie i wdowieństwie konsekrowanym, www.ifzk.episkopat.pl (30.11.2018).

3 Zob. Kongregacja ds. Instytutów Życia Konsekrowanego i Stowarzyszeń Życia Apostolskiego, Ecclesiae Sponsae Imago. Instrukcja na temat „ordo virginum” [dalej: ESI], Pelplin 2019, nr 74-113.
} 
i podano własne propozycje, które mogą być przydatne dla osób opracowujących programy formacyjne dla ordo virginum.

Niniejszy artykuł składa się z trzech części. W pierwszej zostaną poruszone zagadnienia wstępne dotyczące formacji w ordo virginum. W drugiej części zostaną przedstawione uwagi dotyczące rozeznawania powołania oraz propozycje formacji przed konsekracją. Natomiast w części trzeciej zostaną zawarte propozycje dotyczące formacji stałej. Całość zamkną uwagi końcowe.

\section{Zagadnienia wstępne dotyczące formacji w ordo virginum}

W zagadnieniach wstępnych najpierw zostanie poruszona problematyka odpowiedzialnych za formację, ze szczególnym uwzględnieniem samej zainteresowanej, następnie zostaną zaproponowane dwa aspekty formacji teologicznej wynikające ze specyfiki ordo virginum, a na końcu zostaną przedstawione formy kształcenia, które mogą być stosowane w formacji.

\subsection{Odpowiedzialni za formację w ordo virginum}

$\mathrm{W}$ diecezji głównym nauczycielem jest biskup ${ }^{4}$. Dlatego też jego można wskazać jako odpowiedzialnego za formację różnych grup w diecezji, począwszy od seminarzystów i kapłanów, a skończywszy na osobach konsekrowanych, które mają status diecezjalny. Dlatego też w ordo virginum wśród odpowiedzialnych za formację aspirantek, kandydatek i konsekrowanych należy wymienić biskupa diecezjalnego, kapłana zajmującego się w diecezji ordo virginum oraz samą aspirantkę, kandydatkę i konsekrowaną̧5.

Biskup diecezjalny zwykle wyznacza prezbitera, który w jego imieniu troszczy się o formację w ordo virginum. Wydaje się oczywiste, że taki kapłan powinien opracować program formacyjny dla diecezji i przedstawić go biskupowi do akceptacji ${ }^{6}$ W programie tym powinny być wyróżnione etapy formacji oraz

4 Zob. Sobór Watykański II, Konstytucja dogmatyczna o Kościele Lumen gentium [dalej: LG], nr 21, w: Sobór Watykański II, Konstytucje, dekrety, deklaracje. Tekst polski. Nowe tłumaczenie, Poznań 2002, s. 123.

5 Wszyscy oni bywają nazywani formatorami, jako osoby prowadzące formację. Jednakże należy zwrócić uwagę, że głównym i prawdziwym formatorem życia chrześcijańskiego jest Duch Święty i z Nim wszyscy inni powinni współpracować. Jedynie On może zapoczątkować i pogłębiać osobistą relację chrześcijanina z Chrystusem, bez której żadna formacja nie jest możliwa.

$6 \quad \mathrm{Z}$ instrukcji na temat ordo virginum należy wydobyć wskazówki odnoszące się do formacji przed konsekracją i formacji stałej, znajdujące się zwłaszcza w numerach 76-78, 83 i innych. 
na wzór programów katechetycznych powinny być podane szczegółowe cele, treści kształcenia, procedury osiągania celów (zastosowane formy i metody kształcenia) oraz opis założonych osiągnięć osób formowanych. Taki program winien być zweryfikowany wobec konkretnej osoby, bowiem formacja w ordo virginum powinna zachować swój indywidualny charakter. Instrukcja Ecclesiae Sponsae Imago zwraca uwagę na to, by w przygotowaniu ścieżek formacji nie ograniczać się do jednolitych i ogólnych propozycji. Ze względu na specyfikę życia w ordo virginum osoba formowana powinna mieć możliwość wyboru pewnych aspektów swojej formacji i osobistego rozłożenia akcentów ${ }^{8}$.

Najważniejszą osobą odpowiedzialną za formację jest sama aspirantka i kandydatka, a potem konsekrowana. Podobnie sprawa formacji ukazywana jest w odniesieniu do prezbiterów ${ }^{9}$. Także w formacji zakonnej wskazuje się na osobistą odpowiedzialność osoby konsekrowanej za własną formację ${ }^{10}$. Tym bardziej dotyczy to konsekrowanych reprezentujących indywidualną formę życia konsekrowanego. Należy przyjąć, że choć dopuszczenie do konsekracji nie należy do kandydatki, bowiem decyzję tę podejmuje biskup, to samo podjęcie życia $\mathrm{w}$ ordo virginum i związane $\mathrm{z}$ tym rozeznawanie swojego zaangażowania i misji należy do bardzo osobistych aktów samej zainteresowanej. Biskup weryfikuje jej rozeznanie i je potwierdza, ale sam niczego nie narzuca. Taka sytuacja wymaga od kandydatki do życia w ordo virginum dojrzałości osobowej

W formacji należy podkreślać wzór Maryi, która wskazuje drogę konsekrowanym - zob. ESI 114-115. Osobie Maryi poświęcony został odrębny artykuł - zob. B. Stypułkowska, Maryja jako matka, siostra i nauczycielka dla dziewicy konsekrowanej, „Częstochowskie Studia Teologiczne” (w druku).

7 Zob. ESI 77.

8 Wśród dziewic pojawiają się głosy przeciwne sformalizowanej formacji. Jednakże opracowanie programu formacyjnego wydaje się konieczne dla dobra ordo virginum, odróżnienia go od zgromadzeń zakonnych, sprecyzowania specyfiki tej formy życia i konkretnej pomocy dla osób realizujących to powołanie.

9 Zob. Jan Paweł II, Adhortacja apostolska o formacji kapłanów we współczesnym świecie Pastores dabo vobis [dalej: PDV], nr 79, https://www.vatican.va/content/john-paul-ii/pl/apost_exhortations/ documents/hf_jp-ii_exh_25031992_pastores-dabo-vobis.html (14.06.2021); Sobór Watykański II, Dekret o posłudze i życiu kapłanów Presbyterorum ordinis, nr 12-18, w: Sobór Watykański II, Konstytucje, dekrety, deklaracje, dz. cyt., s. 495-504; J. Wątroba, Permanentna formacja duchowa kapłanów w świetle soborowych i posoborowych dokumentów Urzędu Nauczycielskiego Kościoła (1963-1994), Częstochowa 1999, s. 256-259.

10 Zob. Kongregacja Instytutów Życia Konsekrowanego i Stowarzyszeń Życia Apostolskiego, Instrukcja Wskazania dotyczące formacji w instytutach zakonnych „Potissimum Institutioni”, nr 29; www.zyciezakonne.pl/dokumenty/kosciol/kongregacja-instytutow-zycia-konsekrwanegoi-stowarzyszen-zycia-apostolskiego (19.03.2019); „Acta Apostolicae Sedis” 82 (1990), s. 470-532. 
oraz doświadczenia w posłudze kościelnej. Niemożliwe jest zatem zorganizowanie w diecezji formacji do ordo virginum na wzór formacji seminaryjnej czy zakonnej. W większym zakresie potrzebne jest podejście indywidualne do każdej z osób formowanych.

Kapłan odpowiedzialny w diecezji za ordo virginum oraz sama aspirantka, kandydatka i konsekrowana korzystają z pomocy innych osób: kierowników duchowych, spowiedników, rekolekcjonistów, wykładowców. Do odpowiedzialnych należy rozpoznanie autentyczności powołania kandydatki do życia w ordo virginum. Chodzi o rozpoznanie, czy inspiracja wewnętrzna, której doświadcza osoba, pochodzi od Ducha Świętego, i czy zachodzą warunki podmiotowe i przedmiotowe pozwalające na przyjęcie tego daru ${ }^{11}$.

\subsection{Dwa aspekty formacji teologicznej}

W odniesieniu do formacji świeckich wymienia się cztery wymiary: formację ludzką, formację duchową, formację doktrynalną i formację do apostolstwa ${ }^{12}$. Analogicznie w odniesieniu do formacji kapłańskiej mówi się o formacji ludzkiej, formacji duchowej, formacji intelektualnej i formacji duszpasterskiej ${ }^{13}$. Biskup Kiciński w odniesieniu do konsekrowanych uwzględnia w formacji trzy aspekty: ludzki, chrześcijański i charyzmatyczny, przy czym wymiar ludzki i chrześcijański dotyczy wszystkich wiernych, a wymiar charyzmatyczny odnosi się do życia konsekrowanego ${ }^{14}$. Instrukcja Ecclesiae Sponsae Imago mówi o trzech ścieżkach formacyjnych: teologicznej, kulturowej i pastoralnej ${ }^{15}$. W niniejszym artykule uwaga zostanie skoncentrowana głównie na formacji teologicznej.

${ }^{11}$ Por. K. Konecki, Konsekracja dziewic w odnowie liturgicznej Soboru Watykańskiego II. Studium liturgiczno-teologiczne, Włocławek 1997, s. 282; P. Ruaro, Lordine delle vergini. I documenti, i riti, le norme, i principia spirituals e pastorali, Torino 1990, s. 117.

${ }_{12}$ Zob. Sobór Watykański II, Dekret o apostolstwie świeckich Apostolicam actuositatem, nr 28-30, w: Sobór Watykański II, Konstytucje, dekrety, deklaracje, dz. cyt., s. 397-399.

${ }^{13}$ Zob. PDV 43-59.

14 Por. J. Kiciński CMF, Formacja początkowa i stała w dziewictwie $i$ wdowieństwie konsekrowanym, www.ifzk.episkopat.pl (30.11.2018). Wymiar charyzmatyczny może odnosić się do konkretnego powołania życiowego i w znaczeniu ogólnym może być rozpatrywany jako charyzmat życia konsekrowanego, charyzmat życia małżeńskiego czy charyzmat życia kapłańskiego. Pewne sugestie formacyjne podał także ks. Krzysztof Konecki w pierwszym polskim opracowaniu naukowym dotyczącym konsekracji dziewic. Zob. K. Konecki, Konsekracja dziewic w odnowie liturgicznej Soboru Watykańskiego II, dz. cyt., s. 281-296.

${ }^{15}$ Zob. ESI 78. 
Według kodeksu prawa kanonicznego dziewice, wyrażając święty zamiar gruntowniejszego naśladowania Chrystusa - są poświęcone Bogu przez biskupa diecezjalnego według zatwierdzonego obrzędu liturgicznego - zostają zaślubione mistycznie Chrystusowi i przeznaczone na służbę Kościołowi ${ }^{16}$. Opierając się na tej definicji, formację teologiczną w ordo virginum można rozpatrywać $\mathrm{w}$ dwóch aspektach: chrystocentrycznym ${ }^{17}$ (zaślubione mistycznie Chrystusowi) i eklezjalnym (przeznaczone na służbę Kościołowi). Aspekt chrystocentryczny odnosi się do zagadnień związanych z budowaniem więzi z Chrystusem i upodabnianiem się do Tego, któremu dziewica podczas konsekracji zostaje zaślubiona, natomiast aspekt eklezjalny odnosi się do podejmowania służby w Kościele i łączy się z naśladowaniem Chrystusa. Oba aspekty związane są z działaniem Ducha Świętego, a Jego działanie w życiu każdego chrześcijanina, w tym również w życiu konsekrowanych, wynika z przyjęcia sakramentów wtajemniczenia chrześcijańskiego.

Chrystocentryzm formacji będzie dotyczył stawania się „jednym ciałem” z Chrystusem, w myśl św. Pawła, który odnosił ten obraz do Chrystusa i do Kościoła $^{18}$, a związany jest $\mathrm{z}$ poznaniem Chrystusa, by ostatecznie przyswoić sobie Jego sposób myślenia, patrzenia i działania ${ }^{19}$. Upodobnienie się do Chrystusa ${ }^{20}$

${ }_{16}$ Zob. Kodeks prawa kanonicznego [dalej: KPK], Poznań 1983, kan. 604, § 1 .

${ }_{17}$ Chrystocentryzm polega na systematycznym opieraniu teologii i życia duchowego człowieka na Osobie i dziełach zbawczych Jezusa Chrystusa. Por. G. O’Collins, E. G. Farrugia, Zwięzły słownik teologiczny, przekł. J. Ożóg, Kraków 1993, s. 46.

${ }_{18}$ Zob. Ef 5, 32.

19 Por. J. Kiciński CMF, Formacja początkowa i stała w dziewictwie i wdowieństwie konsekrowanym, www.ifzk.episkopat.pl (30.11.2018).

${ }^{20}$ Upodobnienie do Chrystusa zaczyna się w momencie chrztu świętego, który zanurza nas w śmierć Chrystusa (Rz 6, 3). Wówczas z Chrystusem zostajemy przybici do krzyża i odtąd już nie my żyjemy, lecz żyje w nas Chrystus (por. Ga 2, 19-20). Nie chodzi tutaj wyłącznie o nową motywację „życia dla Boga”, ponieważ wiara w Chrystusa nie pełni roli nowego celu postępowania, lecz dostarcza nową podstawę aktywności na poziomie ontycznym, czyli odnoszącym się do istnienia, bytu. Por. J. A. Fitzmyer, List do Galatów, w: Katolicki komentarz biblijny, red. naukowa wyd. oryginalnego R. E. Brown, J. A. Fitzmyer, R. E. Murphy, red. naukowa wyd. polskiego W. Chrostowski, Warszawa 2001, s. 1378. W przypadku konsekracji dziewic kandydatka przystępuje do niej, wyrażając zamiar gruntowniejszego naśladowania Chrystusa (KPK, kan. $604 \$ 1$ ), w czym zawiera się właśnie nowa motywacja poświęcenia się Bogu, życia dla Niego i kochania Go niepodzielnym sercem. Konsekracja dziewicy odbywa się niejako na przedłużeniu chrztu świętego, w którym Chrystus jednoczy się z człowiekiem. Zaślubienie mistyczne przez obrzęd liturgiczny tworzy nową więź między Chrystusem a konsekrowaną, dzięki której osoba konsekrowana otrzymuje nową łaskę do przestrzegania przykazania Boga (Pwt 6, 4-5) i bliźniego (Kpł 19, 11-18), a tym samym wobec innych staje się jakby „przedłużeniem” miłości Chrystusa. 
ściśle jest związane z naśladowaniem Go, a naśladowanie Chrystusa domaga się poznania Jego Osoby przez modlitewne czytanie Pisma Świętego, w czasie którego chrześcijanin otrzymuje Ducha Świętego do wprowadzania słowa Bożego w życie. Aspekt eklezjalny formacji będzie przejawiał się w rozeznawaniu i przygotowaniu kandydatki, a potem osoby konsekrowanej, do pełnienia służby w Kościele. U konsekrowanych chodzi o posługę na rzecz Kościoła diecezjalnego, chociaż za zgodą biskupa może być ona również delegowana do pracy poza diecezją lub w strukturach ogólnokościelnych. Aspekt chrystocentryczny i eklezjalny odnosi się w praktyce do współdziałania z Duchem Świętym. W formacji teologicznej istotne jest nawiązywanie do sakramentów inicjacji chrześcijańskiej i życie liturgią Kościoła. W odniesieniu do sakramentów wtajemniczenia chrześcijańskiego należy przyjąć, że chodzi głównie o namaszczenie i posłanie do świata, jakie dokonuje się w bierzmowaniu. Konsekracja nie jest sakramentem, dlatego też właściwym sakramentem dla realizacji zadań wynikających $\mathrm{z}$ obowiązków ordo virginum jest sakrament bierzmowania. Ksiądz Stanisław Szczepaniec zwrócił uwagę, że „w refleksji nad życiem konsekrowanym bardzo często przechodzi się bezpośrednio od chrztu do daru konsekracji, z pominięciem bierzmowania i jego specyfiki. Trzeba ten brak uzupełnić" ${ }^{21}$. Sugestia ta wydaje się całkowicie słuszna. Osoba konsekrowana powinna „osobiście sprawdzić, w jaki sposób w jej własnym życiu działalność apostolska wypływa z wewnętrznego zjednoczenia z Bogiem i równocześnie to zjednoczenie zacieśnia i umacnia"22. Możliwe jest to przy współpracy z Duchem Świętym, którego umocnienie otrzymała w sakramencie bierzmowania. Służba w Kościele osoby konsekrowanej jest przedmiotem refleksji eklezjologii pneumatologicznej, ponieważ nie wynika ona z urzędu otrzymanego na mocy święceń, lecz ma charakter charyzmatyczny, który wprawdzie przez hierarchię jest rozeznawany i zatwierdzany, ale swoje źródło ma bezpośrednio w Duchu Świętym.

\subsection{Formy kształcenia w ordo virginum}

$\mathrm{W}$ formacji w ordo virginum można zastosować różne formy kształcenia. W dydaktyce forma kształcenia czy nauczania to termin oznaczający organizacyjną stronę nauczania, w odróżnieniu od metody nauczania, która dotyczy

${ }_{21}$ S. Szczepaniec, Od konsekracji chrzcielnej do stanu życia konsekrowanego, www.konsekrowane. org/dokumenty/konferencja_konsekracja_2015.pdf (14.12.2018).

${ }^{22}$ Kongregacja Instytutów Życia Konsekrowanego i Stowarzyszeń Życia Apostolskiego, Instrukcja Wskazania dotyczące formacji w instytutach zakonnych „Potissimum Institutioni”, dz. cyt., nr 18. 
sposobu pracy nauczyciela z uczniami. Forma kształcenia obejmuje zewnętrzne warunki nauczania, a więc dobór uczniów i nauczycieli, połączenie ich w odpowiednie grupy, współpracę grup i jednostek ze sobą, rodzaj zajęć oraz warunki miejsca i czasu pracy dydaktycznej ${ }^{23}$. Ze względu na liczbę uczniów wyróżnia się nauczanie jednostkowe, w grupach, zbiorowe ${ }^{24}$. Formy te mogą być zastosowane $\mathrm{w}$ formacji w ordo virginum, $\mathrm{z}$ tym, że nie wszystkie formy są konieczne. Do obowiązkowej formy kształcenia należy zaliczyć formę indywidualną, do raczej obowiązkowej - formę zbiorową, do dobrowolnej formę grupową.

Rzeczywiście obowiązkowa dla wszystkich jest forma indywidualna, w której stosowana jest zasada indywidualizacji kształcenia. Należy ją preferować w ordo virginum, ponieważ powołanie konsekrowanych jest przede wszystkim powołaniem indywidualnym ${ }^{25}$. Forma indywidualna może być związana $\mathrm{z}$ praktyką samokształcenia kierowanego ${ }^{26}$ oraz z towarzyszeniem duchowym ${ }^{27}$. Samokształcenie kierowane jest względnie samodzielnym uczeniem się pod kierunkiem nauczyciela, który w zależności od potrzeby mniej lub bardziej ingeruje w cele nauczania, treść lub metody ${ }^{28}$. Występują w nim dwa podmioty: podejmujący samokształcenie oraz kierujący samokształceniem ${ }^{29}$. Forma indywidualnego samokształcenia kierowanego w zastosowaniu do formacji w ordo virginum może polegać na systematycznych spotkaniach podejmującej formację z odpowiedzialnym za formację przez określony czas w celu osiągnięcia

${ }^{23}$ Por. W. Okoń, Nowy słownik pedagogiczny, Warszawa 1996, s. 77-78.

${ }^{24}$ Por. C. Kupisiewicz, Podstawy dydaktyki ogólnej, Warszawa 1995, s. 187-189; W. Okoń, Wprowadzenie do dydaktyki ogólnej, Warszawa 1996, s. 326-330.

${ }_{25}$ Por. K. Konecki, Konsekracja dziewic w odnowie liturgicznej Soboru Watykańskiego II, dz. cyt., S. 288.

${ }^{26}$ Por. B. Stypułkowska, Samokształcenie kierowane $w$ formacji biblijnej katechetów, „Polonia Sacra” 11 (XXIX) (2007) nr 21/65, s. 211-231; B. Stypułkowska, Teoretyczne i praktyczne założenia przygotowania katechetów do poprawnej interpretacji tekstów biblijnych z uwzględnieniem form samokształcenia kierowanego, Kraków 1999.

${ }^{27}$ Instrukcja Ecclesiae Sponsae Imago wskazuje na to, że każdy etap ścieżki rozeznawania i formacji wymaga praktyki towarzyszenia duchowego - zob. ESI 79.

${ }^{28}$ Por. W. Okoń, Wprowadzenie do dydaktyki ogólnej, dz. cyt., s. 155.

${ }^{29}$ Czesław Maziarz określa samokształcenie kierowane jako „indywidualne przyswajanie wiedzy, umiejętności i nawyków oraz urabianie cech charakteru, realizowane głównie własnym wysiłkiem osoby kształcącej się i wspomaganie częściowo przez inną osobę, której kierownictwu osoba kształcąca się poddała dobrowolnie" (C. Maziarz, Proces samokształcenia, Warszawa 1966, S. 146). 
ustalonych wyników ${ }^{30}$. Konsekrowana jako główna odpowiedzialna za własną formację powinna sama organizować własne studium. Jednakże odpowiedzialny za formację może wskazywać jej odpowiednie lektury. Dotyczy to zwłaszcza aspirantek i kandydatek. Oprócz zadawanych lektur odpowiedzialny za formację może zaproponować aspirantce i kandydatce uczestniczenie w wybranych wykładach na uczelni teologicznej w randze wolnego słuchacza. Powinien też pomóc zainteresowanej w wyborze przedmiotów i określeniu czasu studiów, a także w pracy samokształceniowej ${ }^{31}$.

Gdy w diecezji jest więcej aspirantek, kandydatek i konsekrowanych, wskazane jest zastosowanie formy zbiorowej. Adekwatne do tej formy będą wykłady, nabożeństwa, wprowadzenia do lectio divina, rekolekcje stanowe. Udział aspirantek, kandydatek i konsekrowanych w wykładach i nabożeństwach jest wskazany, choć w odniesieniu do wykładów winno być również uwzględnione ich różne przygotowanie teologiczne ${ }^{32}$. Rekolekcje stanowe, podobnie jak jest w przypadku liturgii godzin, powinny być „usilnie zalecane”.

Forma grupowa kształcenia winna być dla ordo virginum formą dowolną, choć instrukcja Ecclesiae Sponsae Imago zwraca uwagę na więź komunii między wszystkimi konsekrowanymi obecnymi w danej diecezji ${ }^{33}$, a spotkania

${ }^{30}$ Dydaktycy zwracają uwagę na indywidualizację kształcenia jako niezbędny element systemu edukacyjnego (zob. T. Lewowicki, Indywidualizacja kształcenia. Dydaktyka różnicowa, Warszawa 1977, s. 83), ważny zwłaszcza w prawidłowym kierowaniu samokształceniem innych. Por. C. Maziarz, Proces samokształcenia, dz. cyt., s. 173.

${ }^{31}$ Kierujący samokształceniem na początku pracy winien ocenić umiejętność planowania samodzielnej pracy przez poszczególne osoby. Konsekrowana może mieć trudności ze zdefiniowaniem tematu, określeniem celu, metod i pomocy, zarysowaniem następstwa poszczególnych czynności uczenia się, ustaleniem realistycznych terminów dla poszczególnych etapów pracy. W zależności od stopnia samodzielności podejmującego samokształcenie prowadzący winien dostosować swój wpływ do przebiegu procesu uczenia się. Stefan Pacek wymienia fazy analityczne i realizacyjne działań samowychowawczych, które odnoszą się również do samokształcenia, i zwraca uwagę, że każda $\mathrm{z}$ tych faz wymaga innej interwencji kierującego. Zob. S. Pacek, Jak kierować samowychowaniem uczniów, Warszawa 1984, s. 49-50.

${ }^{32}$ Niektóre wykłady mogą być prowadzone wspólnie dla aspirantek, kandydateki konsekrowanych (np. wykłady związane z sakramentami wtajemniczenia chrześcijańskiego, z zakresu prawa kanonicznego - o obowiązkach osób konsekrowanych i o obowiązkach proboszczów, z którymi konsekrowane współpracują). Nabożeństwa słowa Bożego i wprowadzenia do lectio divina tekstów biblijnych o Chrystusie-Oblubieńcu powinny być również dostępne dla wszystkich chętnych aspirantek, kandydatek i konsekrowanych. Wykłady tylko dla aspirantek będą dotyczyły różnych form życia konsekrowanego. Dla aspirantek również powinien być przewidziany wykład z ćwiczeniami praktycznymi dotyczący odmawiania liturgii godzin.

${ }_{33}$ Zob. ESI 44. 
w małych grupach sprzyjają rozwijaniu tej więzi. Spotkania w grupach mogą być wykorzystane przez odpowiedzialnego za formację do pracy związanej $\mathrm{z}$ zadanymi lekturami. Jednakże i w tym przypadku ze względu na różny poziom wcześniejszego przygotowania teologicznego, jak i potrzeb poszczególnych konsekrowanych forma ta nie może być obowiązkowa. W przypadku formy grupowej warto jednak uwrażliwić osoby konsekrowane na potrzebę doświadczania bliskości z osobami o wspólnym powołaniu. Konsekrowane nie tworzą wspólnoty powołania, polegającej na wspólnej realizacji życia i posługi. Jednakże w formacji wskazane są kontakty między poszczególnymi konsekrowanymi, by unikać tendencji indywidualistycznych, które utrudniają nabywanie i rozwijanie prawdziwego poczucia przynależności eklezjalnej i ducha komunii w ordo virginum ${ }^{34}$. Kontakty indywidualne między konsekrowanymi mogą wydatnie przyczynić się do wzrostu w życiu duchowym, mogą też być punktem odniesienia w przeżywaniu własnego powołania i sprawić, że dana konsekrowana nie będzie podążała samotnie swoją drogą, ale będzie miała z kim dzielić się swoim życiem, doświadczeniem i trudnościami, słuchając innych i sama będąc wysłuchiwana ${ }^{35}$.

\section{Formacja początkowa}

Formacja początkowa składa się z trzech faz: okresu propedeutycznego (okresu podejścia), okresu formacji, odpowiednio podzielonego na kilka etapów z ich własnymi celami i weryfikacjami, oraz ostatecznego rozeznania (skrutynium) ${ }^{36}$. Wyjątkowość formacji początkowej polega na tym, że przekazane treści i ich asymilacja stanowią niejako fundament, do którego nieustannie powraca się w ciągu następnych lat życia ${ }^{37}$.

Formacja, która przygotowuje do życia w ordo virginum, ma swój początek i trwa do momentu konsekracji ${ }^{8}$. Do konsekracji powinny być dopuszczone kobiety dojrzałe, a więc najlepiej w okresie między 25. a 40. rokiem życia, gdyż charakteryzuje się on takim stopniem dojrzałości psychologicznej i społecznej,

${ }^{34}$ Zob. ESI 77.

${ }_{35}$ Na ten problem zwrócił uwagę papież Franciszek - zob. Siła powołania. O życiu konsekrowanym i poprawie relacji $w$ Kościele. Papież Franciszek w rozmowie z Fernando Prado, Poznań 2019, s. 98.

${ }^{36}$ Zob. ESI 81.

37 Por. J. Kiciński CMF, Formacja początkowa i stała w dziewictwie i wdowieństwie konsekrowanym, www.ifzk.episkopat.pl (30.11.2018).

${ }_{38}$ Por. J. Kiciński CMF, Formacja początkowa i stała w dziewictwie i wdowieństwie konsekrowanym, www.ifzk.episkopat.pl (30.11.2018). 
który pozwala na samodzielne życie, włączenie się konstruktywnie w społeczeństwo i wzięcie odpowiedzialności za swe czyny i decyzje ${ }^{39}$. Kandydatki do ordo virginum muszą być dojrzałe osobowościowo oraz powinny mieć uregulowaną sytuację życiową pod względem pracy zawodowej i miejsca zamieszkania.

\subsection{Okres propedeutyczny}

Instrukcja Ecclesiae Sponsae Imago zastrzega, że okres propedeutyczny w żadnym wypadku nie może rozpocząć się przed 18 . rokiem życia ${ }^{40}$. Ma on na celu weryfikację wymagań i warunków niezbędnych do owocnej drogi formacji w związku z konsekracją i trwa zwykle rok lub dwa lata ${ }^{41}$. Zadanie aspirantki do ordo virginum w fazie okresu propedeutycznego polega na zdobyciu wiedzy o istotnych aspektach i formie życia w tym stanie w celu porównania ich $\mathrm{z}$ własną intuicją powołaniową ${ }^{42}$. Natomiast zadanie opiekuna ordo virginum polega na poznaniu aspirantki i pierwszej weryfikacji. Instrukcja Ecclesiae Sponsae Imago podaje szczegółowe wytyczne, którymi należy się kierować na tym etapie ${ }^{43}$, oraz wymagania i kryteria rozeznawania ${ }^{44}$.

Treściami formacji teologicznej w okresie propedeutycznym w odniesieniu do aspektu chrystocentrycznego winna być nauka Jezusa o Duchu Świętym ${ }^{45}$; prawda o Jezusie działającym przez sakramenty święte; przypomnienie wiadomości o sakramentach wtajemniczenia chrześcijańskiego ze szczególnym zwróceniem uwagi na sakrament bierzmowania i możliwość odnowienia łaski tego sakramentu; nauka o siedmiu darach Ducha Świętego jako o pełni Ducha Świętego. Gdy chodzi o aspekt eklezjalny, powinny być poruszone następujące zagadnienia: nauka o hierarchicznym ustroju Kościoła i jego wymiarze charyzmatycznym oraz przybliżenie różnych form życia konsekrowanego, ze szczególnym zwróceniem uwagi na ordo virginum ${ }^{46}$. Na tym etapie aspirantka powinna rozważyć, czy podoła trudom związanym z życiem samotnym,

39 Por. B. Giordani, Wybrane przez Chrystusa. Kobiety konsekrowane. Studium psychologiczne, przekł. K. Kozak, Częstochowa 2004, s. 72-73.

${ }^{40}$ Zob. ESI 82.

${ }^{41}$ Zob. ESI 92.

${ }_{42}$ Zob. ESI 92.

${ }^{43}$ Zob. ESI 93-96.

${ }_{44}$ Zob. ESI 84-88.

45 Woda życia (J 7, 37-39), Paraklet (J 14, 15-20. 25-26; 15, 26-27; 16, 5-15).

${ }^{46} \mathrm{~W}$ niniejszym artykule brak miejsca na szczegółowe przedstawianie treści formacji teologicznej, gdyż wymagałoby to szerszej publikacji. Niżej zostaną przedstawione jedynie wybrane aspekty. 
samodzielnym dbaniem o utrzymanie i formację, ustaleniem i pilnowaniem planu dnia uwzględniającego pory modlitwy, opracowaniem własnego statutu personalnego oraz indywidualnym rozeznawaniem swojej służby w Kościele, która będzie zgodna z oczekiwaniami Chrystusa-Oblubieńca. Wspólnotą wzrostu dla aspirantki, kandydatki, a potem konsekrowanej powinna być wspólnota diecezjalna, w której posługuje: parafia zamieszkania lub instytucja kościelna, w której pracuje. Warto zwrócić na to uwagę już na etapie przyjęcia kandydatki do formacji ${ }^{47}$. Gdy wspólnotą wzrostu jest jakaś inna wspólnota eklezjalna, jakiś ruch czy trzeci zakon, wówczas osoba konsekrowana może nie dostrzegać swego miejsca w strukturach diecezjalnych i pojawi się wątpliwość wobec zasadności włączenia jej do ordo virginum w diecezji.

\subsubsection{Aspekt chrystocentryczny w okresie propedeutycznym}

Aspekt chrystocentryczny będzie dotyczył relacji między Chrystusem a Duchem Świętym w życiu ziemskim Jezusa oraz w Kościele. W odniesieniu do możliwości odnowienia sakramentu bierzmowania warto kierować się nauką św. Tomasza z Akwinu, przybliżoną przez Tomasza Gałuszkę OP ${ }^{48}$. Autor, wyjaśniając myśl wielkiego teologa i mistyka, podaje tezę, że podobnie jak chrzest jest wielokrotnie odnawiany w sakramencie pokuty, tak i istnieje odnowa w łasce dotycząca sakramentu bierzmowania, w której człowiek przyjmuje osobistą misję i dostaje bardzo konkretne dary, potrzebne w tej misji ${ }^{49}$. Sakrament bierzmowania może być wówczas punktem odniesienia dla życia i posługi konsekrowanych.

Dary duchowe, jakie chrześcijanin otrzymuje w sakramencie bierzmowania, służą rozwojowi człowieka (siedem darów Ducha Świętego) oraz rozwojowi wspólnoty (charyzmaty). W okresie propedeutycznym warto zatrzymać się na siedmiu darach Ducha Świętego, których rozwój może pomóc aspirantce $\mathrm{w}$ wyborze drogi powołania, a na dalszym etapie, $\mathrm{w}$ formacji przed konsekracją, warto pochylić się nad rozeznawaniem własnych charyzmatów. Tradycja katolicka, opierając się na tekście Iz $11,2-3^{50} \mathrm{w}$ przekładzie greckiej

47 Zob. ESI 95.

${ }^{48}$ Zob. T. Gałuszka, Odnowa w łasce. Teologia charyzmatów św. Tomasza z Akwinu, Kraków 2018.

49 Zob. T. Gałuszka, Odnowa w łasce, dz. cyt., s. 222-223.

${ }^{50}$ Iz 11, 2-3; Hebrajsko-polski Stary Testament. Prorocy. Przekład interlinearny z kodami gramatycznymi, transliteracją i indeksem słów hebrajskich, red. i wstęp A. Kuśmirek, Warszawa 2008, s. 775. 
Septuaginty ${ }^{51}$ i późniejszej łacińskiej Wulgaty, wylicza siedem darów Ducha Świętego: dar mądrości, dar rozumu, dar rady, dar męstwa, dar umiejętności, dar pobożności i dar bojaźni Bożej ${ }^{52}$. W synagodze w Nazarecie na początku swojej publicznej działalności Jezus słowami proroka Izajasza scharakteryzował swoją misję jako posługę wykonywaną w Duchu Świętym. Tekst Izajasza ukazuje Mesjasza, na którym spoczywa Duch Święty. Naśladowanie Chrystusa polega przede wszystkim na otwarciu się na Ducha Świętego i uległości wobec Niego. Duch Święty udziela chrześcijaninowi swoich darów, a Jego obecność poznaje się po owocach.

${ }^{51}$ Iz 11, 2-3; Septuaginta. Id est Vetus Testamentum graece iuxta LXX interpreter edidit Alfred Rahlfs, Stuttgart 1979, s. 581.

${ }^{52}$ Zob. Katechizm Kościoła Katolickiego, Poznań 1994, nr 1831. W oryginalnym tekście hebrajskim mamy wymienionych sześć darów Ducha Świętego połączonych w trzy pary: duch mądrości i rozumu rûah hokmāh ûbînah, duch rady i męstwa rûah écā ûgebûrāh, duch umiejętności i bojaźni Jahwe rûah da'at wejirat JHWH. Liczba siedmiu darów wynika z tego, że powtarzający się w wierszach $2 \mathrm{~d}$ i za hebrajski termin jir'at w Septuagincie [dalej: LXX] został przetłumaczony przez dwa określenia: „pobożność” (eusebeia) oraz „bojaźń Bożą” (fobos Theou) - por. T. Brzegowy, Księga Izajasza, rozdziały 1-12. Wstęp-przekład z oryginału-komentarz, Częstochowa 2010, s. 613. Prawdopodobnie tłumacze chcieli uniknąć powtórzenia tego samego wyrazu - zob. Pismo Święte Starego i Nowego Testamentu w przekładzie z języków oryginalnych ze wstępem i komentarzami, oprac. zespół pod red. M. Petera (Stary Testament), M. Wolniewicza (Nowy Testament), t. 3: Stary Testament, Księga Izajasza, Księga Jeremiasza, Księga Barucha, Księga Lamentacji (Treny), Księga Ezechiela, Księga Daniela, 12 Proroków Mniejszych [dalej: BP], Poznań 1992, s. 40. Za LXX poszła Vulgata, która w pierwszym przypadku ma pietas („pobożność”), a w drugim timor Domini („bojaźń Pańska”). Święty Hieronim przy tłumaczeniu Vulgaty zdawał sobie sprawę z nieścisłości LXX, lecz głównie ze względu na powagę niektórych ojców greckich, którzy na podstawie tekstu LXX przyjęli już liczbę siedmiu darów Ducha Świętego, pozostawił odmienne wyrazy. Egzegeci współcześni, podtrzymujący liczbę siedmiu darów w tekście Izajasza, wskazują jednak nie na w. 3a, lecz na w. 2a mach Jahwe, który wszakże nie stanowi osobnego daru, lecz oznacza samego Jahwe jako Dawcę tych pozostałych darów (BP, s. 40). W Biblii liczba siedem ma sens symboliczny - oznacza pełnię i całość. Por. M. Lurker, Słownik obrazów i symboli biblijnych, tłum. K. Romaniuk, Poznań 1989, s. 212-213. Pełnia darów Ducha Jahwe uzdolni nowego Króla przyszłości do rządów sprawiedliwych (por. też w. 5) i doskonałych. Będzie się to przejawiać we wszystkich dziedzinach rządzenia, choć prorok podkreśla przede wszystkim jego maksymalne wyczucie sprawiedliwości w sądzeniu i troskę o ubogich (anawim). Wymienione dary zostały przyrzeczone przyszłemu królowi Izraela. Później odniesiono je do Mesjasza, który miał posiadać ich pełnię. Zapowiadany Mesjasz będzie obdarzony pełnią darów. Por. J. Kudasiewicz, Odkrywanie Ducha Świętego. Medytacje biblijne, Kielce 1998, s. 82. W taki właśnie sposób ukazuje Nowy Testament Jezusa Chrystusa. Jest On namaszczony Duchem Świętym. Działa i naucza nie tak, jak uczeni w Piśmie, ale jak Ten, który ma władzę. Dopiero w świetle Nowego Testamentu, w odniesieniu do Chrystusa, możemy zrozumieć przesłanie starotestamentalnych zapowiedzi. 


\subsubsection{Aspekt eklezjalny w okresie propedeutycznym}

Aspekt eklezjalny będzie dotyczył różnych forma życia konsekrowanego. Chodzi przede wszystkim o wskazanie podobieństw i różnic, jakie występują między instytutami świeckimi a ordo virginum. Gdy chodzi o instytuty świeckie, to ich zadaniami zwykle nie jest podejmowanie specjalnych dzieł apostolskich. Zasadniczym terenem apostolskiego oddziaływania członkiń instytutów świeckich jest ich środowisko świeckiej pracy zawodowej, rodzina oraz cała sfera życia społecznego, kulturalnego, gospodarczego i towarzyskiego, nie wyłączając parafii ${ }^{53}$. Sama obecność w świecie ma być apostolska, choć ich konsekracja jest ukryta przed światem. Inaczej jest w przypadku ordo virginum. W odróżnieniu od członkiń instytutów świeckich konsekrowana pełni swoją misję otwarcie, jako osoba publiczna, ponieważ akt konsekracji jest publiczny. Poza tym kodeks prawa kanonicznego mówi o służbie Kościołowi ${ }^{44}$. Dziewica jest wyraźnie przeznaczona do służby w Kościele, którą pełni jako osoba konsekrowana. Tę służbę w Kościele należy wyróżnić jako czynnik charakteryzujący konsekrowaną i określający specyfikę jej apostolstwa ${ }^{55}$.

\subsection{Formacja przed konsekracją}

Po okresie propedeutycznym biskup dopuszcza aspirantkę do formacji poprzedzającej konsekrację $e^{56}$. W czasie tej formacji kandydatka powinna złożyć ślub czystości w indywidualnej modlitwie, który będzie miał charakter ślubu prywatnego $^{57}$. Dlatego też formację przed konsekracją można podzielić na dwa

53 Por. W sercu świata. Świeccy konsekrowani, Kraków 1994, s. 21.

54 Zob. KPK, kan. 604, $\$ 1$.

55 Być może jest to jeszcze niedostatecznie podkreślane na etapie formacji początkowej, gdyż na spotkaniu Podkomisji KEP ds. IFŻK, Centrum Promocji IFŻK oraz diecezjalnych referentów ds. IFŻK w dniach 20-21 kwietnia 2018 roku we Wrocławiu zwrócono uwagę na to, że konieczne jest włączenie osób konsekrowanych w życie diecezji w formie ustalonej z osobą konsekrowaną zob. www.ifzk.episkopat.pl/dokumenty/wroclaw_2018.pdf (3.04.2019). Wydaje się, że w myśl prawa kanonicznego nie tylko chodzi o „włączenie w życie”, ale o wyznaczenie konkretnej służby (por. KPK, kan. $604 \$ 1$ ). W Polsce nie jest to jeszcze oczywiste. Na jednym ze spotkań Podkomisji KEP ds. IFŻK zaproponowano przeprowadzenie ankiety dotyczącej tego, co konsekrowane robią, a co chciałyby robić, w szczególności w Kościele. Chodzi o spotkanie z dnia 26 stycznia 2017 r. w Warszawie - zob. www.ifzk.episkopat.pl/o1_2017.php (3.04.2019).

${ }^{56}$ Zob. ESI 96.

57 Rozeznawanie tego kroku powinno dokonywać się z pomocą spowiednika. Należy się zastanowić, czy właściwa jest stosowana niekiedy forma publiczna o charakterze ślubu czasowego, na wzór formacji zakonnej. W czasie formacji początkowej kandydatka w dowolnej chwili może wycofać się z przygotowania do konsekracji i nie powinna być związana żadnym przyrzeczeniem. 
etapy: etap przed złożeniem prywatnego ślubu czystości oraz etap po złożeniu tego ślubu. Etap przed złożeniem prywatnego ślubu czystości winien być dla kandydatki czasem ostatecznego wyboru odnośnie do ordo virginum. Formacja początkowa może być przedłużona na prośbę kandydatki lub w wyniku decyzji ze strony odpowiedzialnych, lecz nie może być nieograniczona w czasie. Po ustalonym terminie winna być zakończona, albo dopuszczeniem do konsekracji (admissio), albo niedopuszczeniem. W tym drugim przypadku w myśl prawa kanonicznego ślub czystości wygasa w skutek niespełnienia się warunku, od którego ślub jest uzależniony ${ }^{58}$. Tym warunkiem może być dopuszczenie do konsekracji, w czasie której następuje publiczne ponowienie przyrzeczenia życia w dozgonnej czystości ${ }^{59}$.

Złożenie ślubu prywatnego, chociaż powinno być konsultowane ze spowiednikiem, nie wymaga żadnych pośredników czy świadków. Dokonuje się indywidualnie podczas osobistej modlitwy. Istotą tego ślubu jest przyrzeczenie, że będzie się kochać Boga sercem niepodzielnym. Nie ma uzasadnienia dla ponawiania tego przyrzeczenia, chyba że chodzi o ślub publiczny, jaki ma miejsce podczas konsekracji. W obrzędzie konsekracji dziewic, tuż przed modlitwą konsekracyjną, występuje moment, w którym kandydatka w sposób publiczny odnawia przyrzeczenie zachowania czystości zob. Pontyfikał rzymski, odnowiony zgodnie z postanowieniem Świętego Soboru Powszechnego Watykańskiego II wydany z upoważnienia papieża Pawła VI, poprawiony staraniem papieża Jana Pawła II, Obrzędy konsekracji konsekrowanych. Wydanie wzorcowe, Katowice 2001, nr 22-23. Kontekst prawny konsekracji konsekrowanych różni się od kontekstu prawnego profesji zakonnej. Wyraźne sformułowanie ślubu podczas liturgii nie jest obowiązkowe: „Jeżeli okoliczności za tym przemawiają, dziewice przez ręce biskupa ofiarują Bogu swoje postanowienie, np. w ten sposób: dziewice pojedynczo podchodzą do biskupa i klękają, następnie złożone ręce kładą w dłonie biskupa i mówią: Ojcze, przyjmij postanowienie życia w doskonałej czystości i naśladowania Chrystusa, które z Bożą pomocą odnawiam wobec ciebie i świętego ludu Bożego" (Obrzędy konsekracji konsekrowanych, dz. cyt., nr 22). Ustawodawca liturgiczny chciał zaznaczyć, że podobnie jak w starożytności, tak i dziś, aby kandydatka mogła otrzymać konsekrację z rąk biskupa, wystarczy, że złoży ślub czystości w sposób prywatny, czyli w swoim sercu, i objawi go podczas duszpasterskiej rozmowy z biskupem - por. K. Konecki, Konsekracja dziewic w odnowie liturgicznej Soboru Watykańskiego II, dz. cyt., s. 196-197. W czasie liturgii kandydatka odnawia przyrzeczenie. Ślub czystości jest złożony wcześniej, w jej sercu, przed Bogiem. W czasie konsekracji ślub czystości nabiera dopiero charakteru publicznego. Niekiedy kandydatka przez dłuższy okres życia wypełnia obowiązki, które przynależą do ordo virginum, i nie można powiedzieć o jakiejś zasadniczej zewnętrznej zmianie w jej życiu, gdy przystępuje do formacji początkowej. Kilkuletni okres przygotowania do poświęcenia się Bogu i w tym przypadku jest konieczny, gdyż umożliwia on nabycie odpowiedniej dyspozycji wewnętrznej do przyjęcia konsekracji.

${ }_{58}$ Zob. KPK, kan. 1194.

59 Oczywiście osoba niedopuszczona do konsekracji może nadal żyć prywatnym ślubem czystości, nie będzie jednak kandydatką do ordo virginum. Wszelkie wątpliwości dotyczące powołania życiowego winna ona rozstrzygać ze swoim spowiednikiem. 
Zadanie kandydatki do ordo virginum na etapie formacji przed konsekracją polega na rozwijaniu więzi oblubieńczej z Chrystusem i przygotowaniu się duchowym do złożenia ślubu czystości oraz życia w ordo virginum, w czym może pomóc przygotowanie statutu personalnego, który miałby ustalać pewne kierunki życia. Zadanie kierownika duchowego polega na potwierdzeniu jej decyzji, pomocy w rozwijaniu oblubieńczej więzi z Chrystusem i przygotowywaniu się do liturgicznych zaślubin lub przedstawieniu swoich wątpliwości dotyczących jej powołania do ordo virginum. Zadanie opiekuna ordo virginum polega na kierowaniu formacją początkową z uwzględnieniem sytuacji jednostkowej kandydatki oraz wstępnej weryfikacji jej zdatności do życia w ordo virginum w celu przedstawienia swojej opinii biskupowi diecezjalnemu ${ }^{60}$.

Treściami formacji teologicznej w odniesieniu do aspektu chrystocentrycznego winny być zagadnienia naśladowania Chrystusa w kontekście obowiązków konsekrowanych; a dalej tajemnica Chrystusa-Oblubieńca Kościoła. Celem formacji na tym etapie jest gruntowniejsze naśladowanie Chrystusa, które zakłada poznanie Go i budowanie z Nim więzi jako Oblubieńcem. Cel ten może być zrealizowany jedynie przez osobistą modlitwę kandydatki i pracę nad sobą pod kierunkiem stałego spowiednika, a charakter takiej pracy ma zawsze zakres indywidualny. Natomiast w odniesieniu do aspektu eklezjalnego powinna być przekazana nauka o charyzmatach. Wśród celów formacji eklezjalnej można wymienić zapoznanie się z charyzmatem życia konsekrowanego (charyzmat prorocki), zapoznanie się z charyzmatem ordo virginum (charyzmat bycia znakiem Kościoła-oblubienicy), poznanie obowiązków konsekrowanych

${ }^{60}$ Pierwsza weryfikacja należy do kierownika duchowego lub spowiednika - por. K. Konecki, Konsekracja dziewic w odnowie liturgicznej Soboru Watykańskiego II, dz. cyt., s. 282; P. Ruaro, Lordine delle vergini, dz. cyt., s. 117. Odpowiedzialny za formację nie może jednak oczekiwać od kierownika duchowego lub spowiednika opinii dotyczącej kandydatki - zob. ESI nr 79. Dlatego też w tej materii winien polegać na słowach samej zainteresowanej i powinien ją spytać, jaka jest opinia jej spowiednika i kierownika duchowego. Rozpoznanie dalsze powinno dotyczyć oceny dojrzałości ludzkiej i duchowej, która daje rękojmię właściwej motywacji i gwarantuje życie w dozgonnej czystości. Pomocą w tej ocenie będą rozmowy odpowiedzialnego z kandydatką oraz opinie osób postronnych. Z rozmów powinny zostać sporządzone notatki, a opinie osób postronnych przedstawione na piśmie. Właściwe jest uwzględnienie pragnienia kandydatek oddania się na służbę Kościołowi diecezjalnemu, ich dyspozycyjności i otwartości na potrzeby Kościoła oraz umiejętności prowadzenia życia w samotności i ich odniesienie do Chrystusa - por. K. Konecki, Konsekracja dziewic w odnowie liturgicznej Soboru Watykańskiego II, dz. cyt., s. 283-284. Ostateczna decyzja o dopuszczeniu do konsekracji należy do biskupa diecezjalnego, który nawet wtedy, gdy osobiście zna kandydatkę, winien mieć wgląd w opinie i świadectwa dotyczące kandydatki, sporządzone przez kapłana odpowiedzialnego za formację oraz inne osoby. 
i rozpoznanie własnych charyzmatów. Cele te będą możliwe do zrealizowania przez uwrażliwienie na działanie Ducha Świętego i podjęcie refleksji nad zagadnieniami związanymi z darami i owocami Ducha Świętego oraz charyzmatami i ich rolą w budowaniu Kościoła, a także określenie swojej posługi kościelnej. Niezmiernie ważna jest jeszcze przed konsekracją konkretyzacja obowiązków konsekrowanych w ordo virginum. Może temu służyć sporządzenie przez kandydatkę statutu personalnego, który będzie zawierał informacje dotyczące jej życia i posługi kościelnej.

\subsubsection{Aspekt chrystocentryczny $w$ formacji przed konsekracja}

Aspekt chrystocentryczny formacji teologicznej jest związany z naśladowaniem Chrystusa. Kodeks prawa kanonicznego, mówiąc o instytutach życia konsekrowanego, zwraca uwagę na różne aspekty naśladowania Chrystusa. Są instytuty, które naśladują Chrystusa, „czy to modlącego się, czy głoszącego królestwo Boże, czy czyniącego ludziom dobrze, czy też obcującego z nimi w świecie” czytamy w kan. 577. Naśladowanie Chrystusa może mieć zatem konkretny wyraz i odzwierciedlenie w instytutach oddanych całkowicie kontemplacji ${ }^{61}$, $\mathrm{w}$ instytutach oddanych dziełom apostolskim ${ }^{62}$, w instytutach świeckich ${ }^{63}$ oraz w stowarzyszeniach życia apostolskiego ${ }^{64}$. Owa typologia wyrażona przez dokumenty kościelne nawiązuje do soborowej nauki o Kościele ${ }^{65}$. W przypadku ordo virginum wymieniono wiele różnorodnych obowiązków: od pokuty, przez dzieła miłosierdzia i dzieła apostolskie po gorliwą modlitwę ${ }^{66}$. Pokuta jest wymieniona na pierwszym miejscu. O pokucie, rozpatrywanej w kontekście krzyża, można mówić w odniesieniu do naśladowania Chrystusa. Ewangeliści podają przekaz o Jezusie poszczącym czterdzieści dni na pustyni. Jest to czyn

${ }^{61}$ Zob. Jan Paweł II, Adhortacja apostolska o życiu konsekrowanym i jego misji w świecie Vita consecrata [dalej: VC], $\mathrm{nr}$ 8, https://www.vatican.va/content/john-paul-ii/pl/apost_exhortations/ documents/hf_jp-ii_exh_25031996_vita-consecrata.html (14.06.2021).

${ }^{62}$ Zob. VC 9.

${ }^{63}$ Zob. VC 10.

${ }^{64}$ Zob. VC 11.

${ }^{65}$ W Konstytucji dogmatycznej o Kościele czytamy: „Zakonnicy gorliwie starać się mają o to, aby za ich pośrednictwem Kościół z biegiem czasu coraz lepiej, zarówno wiernym, jak i niewierzącym, ukazywał Chrystusa - bądź to oddalającego się kontemplacji na górze, bądź zwiastującego rzeszom Królestwo Boże, bądź uzdrawiającego chorych i ułomnych, a grzeszników nawracającego do cnoty, bądź błogosławiącego dzieciom i dobrze czyniącego wszystkim, a zawsze posłusznego woli Ojca, który Go posłał" (LG 46).

${ }^{66}$ Zob. Obrzędy konsekracji konsekrowanych, dz. cyt., Wprowadzenie ogólne, nr 2. 
pokutny. Chrystus nie pokutował za popełnione grzechy, bo to Go nie dotyczyło, ale złożył siebie samego w ofierze za grzechy. Bóg „zwalił na Niego winy nas wszystkich" (Iz 53, 6). Podjęcie męki i śmierci na krzyżu winno być rozpatrywane jako ekspiacja za grzechy ludzi całego świata. Konsekrowana może pokutować za własne grzechy oraz grzechy innych. Czynienie miłosierdzia jest naśladowaniem Chrystusa, który namaszczony Duchem Świętym i mocą, przeszedł dobrze czyniąc i uzdrawiając wszystkich ${ }^{67}$. Podjęcie apostolstwa jest naśladowaniem Chrystusa, który wzywał do nawrócenia i głosił Ewangelię ${ }^{68}$. Wzorem modlitwy jest Jezus, oddawanie się modlitwie jest Jego naśladowaniem. Modlitwa dostępna jest dla wszystkich konsekrowanych. Bez względu na stan zdrowia, predyspozycje czy wykształcenie każda konsekrowana może i powinna oddawać się gorliwej modlitwie, bo dzięki niej buduje relację z Chrystusem-Oblubieńcem oraz może wstawiać się do Boga w sprawach innych ludzi. Naśladowaniu Chrystusa służą dary i owoce Ducha Świętego, które są wynikiem działania Ducha Świętego lub znakiem Jego działania. W działaniu Ducha Świętego rozróżnia się podwójny aspekt: natchnienie i dary. Natchnienie jest to Jego oddziaływanie na umysł i wolę człowieka. Do tego, aby człowiek był posłuszny natchnieniom, Duch Święty przygotowuje go, udzielając swoich darów ${ }^{69}$. Należy liczyć się z tym, że w życiu konkretnych osób żyjących konsekracją jeden $z$ tych obowiązków będzie przeważał i nadawał specyficzny charakter gruntowniejszemu naśladowaniu Chrystusa.

\subsubsection{Aspekt eklezjalny $w$ formacji przed konsekracja}

Aspekt eklezjalny formacji teologicznej związany jest z charyzmatami. Biskup Kiciński uwzględnia w formacji trzy aspekty: ludzki, chrześcijański i charyzmatyczny. Wymiar charyzmatyczny jest według niego bezpośrednio związany z życiem konsekrowanym. Formacja w wymiarze charyzmatycznym dziewic i wdów, według bp. Kicińskiego ma dwa cele: ogólny i specyficzny. Cel ogólny polega na wprowadzeniu w życie konsekrowane i powiązaniu go z tajemnicą Kościoła, a cel specyficzny zawarty jest w bogactwie charyzmatu (dziewictwa

${ }^{67}$ Zob. Dz 10, 38.

${ }^{68} \mathrm{Mk} \mathrm{1,14-15.}$

${ }^{69}$ Por. R. Jasiak, Dary Ducha Świętego, w: Leksykon duchowości katolickiej, red. M. Chmielewski, Lublin-Kraków 2002, s. 191. Święty Tomasz z Akwinu podaje, że „dary to pewne doskonałości człowieka, przysposabiające go do podążania za natchnieniem Ducha Świętego" (św. Tomasz z Akwinu, Suma teologiczna, t. 11, tłum. F. W. Bednarski, London 1965, Zagadnienie 68: O darach Ducha Świętego, s. 224 [STh 1-2, q. 68 a. 3]). 
lub wdowieństwa) ${ }^{70}$. W niniejszym artykule zaproponowano tematykę związaną z charyzmatem życia konsekrowanego w ujęciu ogólnym z uwzględnieniem specyfiki ordo virginum oraz zagadnienie charyzmatów osobistych, które będą odnosiły się do konkretnej osoby.

\subsubsection{Charyzmat życia konsekrowanego}

Formacja podstawowa kandydatek do stanu konsekrowanych powinna odnosić się do sakramentów wtajemniczenia chrześcijańskiego; ukazać charyzmat prorocki związany z życiem konsekrowanym, $\mathrm{w}$ tym charyzmat dotyczący ordo virginum, który polega na byciu znakiem oblubienicy-Kościoła poślubionej Oblubieńcowi-Chrystusowi oraz dotyczyć sposobów naśladowania Chrystusa, z czym związane jest odkrywanie własnych charyzmatów i przygotowywanie się do służenia przez nie w Kościele diecezjalnym.

Jan Paweł II zwrócił uwagę na to, że każda forma życia konsekrowanego przyczynia się do odnowy świata, a osoby konsekrowane są prawdziwym znakiem Chrystusa w świecie ${ }^{71}$. Konsekrowana ma się jednoczyć z tym dążeniem Kościoła, który jako oblubienica dochowuje wiary danej Oblubieńcowi, a jako matka i nauczycielka pragnie przekazać Ewangelię w całej jej autentyczności ${ }^{72}$. Przekazywanie Ewangelii może dokonywać się przez posługę słowa,

${ }^{70}$ Por. J. Kiciński CMF, Formacja początkowa i stała w dziewictwie i wdowieństwie konsekrowanym, www.ifzk.episkopat.pl (30.11.2018).

${ }^{71}$ Zob. VC 25. Można to uznać za ogólny charyzmat życia konsekrowanego. Jest on inaczej realizowany przez mniszki klauzurowe, siostry zakonne i świeckich konsekrowanych. Dziewice konsekrowane niekiedy porównywane są do członkiń instytutów świeckich ze względu na swój sposób życia i posłannictwo. Wszyscy świeccy są przeznaczeni do dawania świadectwa Chrystusowi na mocy sakramentu chrztu i bierzmowania. Konsekrowani żyjący w świecie zobowiązani są do tego dodatkowo przez akt konsekracji.

${ }^{72}$ Zob. Kongregacja ds. Duchowieństwa, Dyrektorium ogólne o katechizacji, Poznań 1997, nr 236. W adhortacji Vita consecrata Jan Paweł II jako wzór życia konsekrowanego wskazał proroka Eliasza, który żył w obecności Boga i w milczeniu kontemplował Jego obecność, wstawiał się za swoim ludem i odważnie ogłaszał Bożą wolę, bronił praw Boga i występował w obronie ubogich przeciw możnym tego świata. Prawdziwe proroctwo również dzisiaj ma swój początek w Bogu, w przyjaźni z Nim, w uważnym wsłuchiwaniu się w Jego słowa - zob. VC 84. Ci, którzy żyją konsekracją, mają czytać Pismo według Ducha Świętego w Kościele, tak aby cały lud Boży mógł z tego korzystać - zob. VC 83. Yves Congar, mówiąc o prorokach w Kościele wskazał, że charakteryzuje ich szczególne poznanie rzeczy Bożych, poznanie lub misja odnoszące się do realizacji planu Bożego oraz przepowiadanie przyszłości, rozumiane również jako intuicje rzeczy skrytych czy też mających nadejść - zob. Y. Congar, Prawdziwa i fałszywa reforma w Kościele, przekł. A. Ziernicki, Kraków 2001, s. 218-228. Wspomniany autor zwrócił uwagę na to, że prorokiem można nazwać kogoś, kto z urzędu pełni funkcję nauczycielską w Kościele - zob. Y. Congar, Prawdziwa i fałszywa reforma $w$ Kościele, dz. cyt., s. 219, a więc biskupa i uczestniczącego w tym charyzmacie katechetę. 
ale również przez świadectwo życia. To w tym kontekście Jan Paweł II pisał o tym, że życie konsekrowane jest szczególną formą uczestniczenia w prorockiej funkcji Chrystusa ${ }^{73}$. Przez prorockie świadectwo wyraża pierwszeństwo Boga i ewangelicznych wartości w życiu chrześcijanina ${ }^{74}$. W przypadku stanu konsekrowanych życie konsekrowane jest szczególnym eschatologicznym obrazem niebiańskiej oblubienicy i przyszłego życia, w którym Kościół zazna pełni miłości do Chrystusa-Oblubieńca ${ }^{75}$. Wymiar oblubieńczy, który ma szczególne znaczenie w życiu konsekrowanym, ukazuje to, że Kościół powinien oddawać się w pełni swemu Oblubieńcowi, od którego otrzymuje wszelkie dobro. W tym wymiarze, właściwym dla całego życia konsekrowanego, zwłaszcza kobieta odnajduje swoją tożsamość, odkrywając w nim szczególny walor swej relacji z Chrystusem ${ }^{76}$. Podczas konsekracji dziewica otrzymuje nową misję w Kościele, co może wiązać się również z nowymi charyzmatami lub rozwinięciem charyzmatów, które już posiada. W homilii znajdującej się w Obrzędach konsekracji konsekrowanych biskup mówi, że Duch Święty przez jego pośrednictwo udziela dziewicy nowego namaszczenia duchowego ${ }^{77}$, a we wprowadzeniu ogólnym do tych obrzędów mowa jest wprost o tym, że przez obrzęd konsekracji dziewic „Kościół wyraża swą miłość do dziewictwa oraz błaga w nim Boga o łaskę dla dziewic i o zstąpienie na nie Ducha Świętego"78.

Charyzmat życia konsekrowanego realizuje się w Kościele w ramach prawa i w uległości wobec hierarchii. Dlatego też w czasie formacji początkowej kandydatka powinna poznać podstawowe dokumenty kościelne, które odnoszą się do stanu konsekrowanych i zawierają normy, wskazania i zalecenia. Chodzi tutaj o adhortację Jana Pawła II Vita consecrata, instrukcję Ecclesia Sponsae Imago, Obrzędy konsekracji konsekrowanych i Kodeks prawa kanonicznego. Oprócz tego przedmiotem formacji powinny być przepisy prawa kanonicznego dotyczące wszystkich wiernych oraz osób konsekrowanych zastosowane w zakresie ich odniesienia do ordo virginum.

\subsubsection{Charyzmaty osobiste}

Zagadnienie działania Ducha Świętego i związanej z tym służby w Kościele wchodzi w zakres tematyki eklezjalnej. Zmiany w człowieku spowodowane

\footnotetext{
${ }_{73}$ Zob. VC 84.

${ }^{74}$ Zob. VC 84.

75 Zob. VC 7.

${ }^{76}$ Zob. VC 34 .

77 Zob. Obrzędy konsekracji konsekrowanych, dz. cyt., s. 19.

${ }^{78}$ Obrzędy konsekracji konsekrowanych, dz. cyt., s. 9.
} 
obecnością Ducha Świętego i dary, które daje On poszczególnym osobom, nie służą tylko rozwojowi jednostek. Chrześcijanie powinni z nich korzystać dla wspólnego dobra ${ }^{79}$. Celem, dla którego Duch udziela swoich darów, jest zbudowanie chrześcijan ${ }^{80}$. Określenie „zbudować” wywołujące skojarzenia $\mathrm{z}$ budową domu sugeruje, że wierni zostali włączeni w pewien proces wzrastania, dojrzewania i umacniania. Paweł nawołuje chrześcijan do uczestnictwa w tym procesie i korzystania z uzdolnień otrzymanych od Ducha Świętego, przy czym daje do zrozumienia, że budowanie Kościoła jest ostatecznie dziełem Ducha Świętego ${ }^{81}$. Całe działanie Ducha Świętego zmierza ku temu, aby nam umożliwić dostęp do Boga, aby nas wprowadzić w żywy kontakt $\mathrm{z} \mathrm{Nim}^{82}$. Dziewice konsekrowane w odróżnieniu od członkiń instytutów świeckich nie żyją we wspólnocie powołania, czyli wspólnocie formacyjno-duchowej, która byłaby narzędziem służącym określonej misji ${ }^{{ }^{3}}$. Konsekrowana sama odpowiedzialna jest za swoją misję. Zadaniem świeckich konsekrowanych jest apostolstwo w świecie i wobec świata ${ }^{84}$, a w przypadku ordo virginum jest nim ponadto wyraźne przeznaczenie na służbę Kościołowi ${ }^{85}$. Służba Kościołowi dotyczy wykonywania konkretnej posługi na rzecz Kościoła diecezjalnego. W niektórych przypadkach służba ta może wykraczać poza ramy diecezji lub być pełniona poza diecezją. Niekoniecznie jest ona związana bezpośrednio $\mathrm{z}$ wykonywaną pracą zawodową, ponieważ konsekrowana może w różny sposób zdobywać środki na swoje utrzymanie.

Zagadnienie służby Kościołowi związane jest z nauką o charyzmatach. Charisma jest to łaska Boża, którą otrzymuje się bez żadnej własnej zasługi, jest to łaska bądź szczególny dar udzielony wierzącemu dla poszerzania, budowania i umacniania wspólnoty Kościoła jako żywego Ciała Chrystusa ${ }^{86}$. Niektórzy uważają, że z pism św. Pawła nie można wysnuć takiego wniosku. Ksiądz

79 Zob. 1 Kor 12, 7; 14, 5. 26; T. Paige, Duch Święty, w: Słownik teologii św. Pawła, red. G. F. Hawthorne, R. P. Martin, D. G. Reid, red. naukowa wyd. polskiego K. Bardski, Warszawa 2010, s. 165.

8o Zob. 1 Kor 14, 1-5. 26.

${ }^{81}$ Por. T. Paige, Duch Święty, dz. cyt., s. 166.

82 Por. J. Guillet, Duch Boży, dz. cyt., s. 234.

${ }_{33}$ Por. M. Chmielewski, Cechy instytutów świeckich, www.kkis.episkopat.pl/abc-instytutowswieckich/cechy-is (23.03.2019).

${ }^{84}$ Por. M. Chmielewski, Cechy instytutów świeckich, www.kkis.episkopat.pl/abc-instytutowswieckich/cechy-is (23.03.2019).

${ }_{85}$ Zob. KPK, kan. $604 \$ 1$.

${ }^{86}$ Por. J. Strong, Grecko-polski słownik Stronga z lokalizacją słów greckich i kodami Popowskiego, Warszawa 2015, s. 829 . 
Grzegorz Rafiński stwierdza, że charyzmat w sensie technicznym jest specyficznym darem udzielonym tylko niektórym oraz że nie jest uzasadnione posługiwanie się tym terminem w znaczeniu funkcji prospołecznej ${ }^{87}$. W Pierwszym Liście do Koryntian św. Paweł pisze o tym, że każdy w zgromadzeniu otrzymał jakiś dar ${ }^{88}$. Podobnie w Liście do Efezjan jest mowa o tym, że każdemu została dana łaska według miary daru Chrystusowego ${ }^{89}$. Świadczyłoby to o tym, że charyzmaty nie są dostępne tylko dla niektórych. W adhortacji Christifideles laici Jan Paweł II wyraźnie mówi o tym, że charyzmaty, czy to nadzwyczajne, czy zwyczajne, działają zawsze pośrednio lub bezpośrednio dla dobra Kościoła, wnosząc swój wkład - zgodnie ze swym przeznaczeniem - w budowanie ludzkiego dobra i w zaspokajanie potrzeb świata. Ci, którzy je otrzymują, mają ich używać dla budowania całego Kościoła ${ }^{90}$. Dokument papieski nie mówi o tym, że każdy chrześcijanin jest charyzmatykiem. Mowa jest tylko o tym, że charyzmaty otrzymują poszczególne osoby i że obecnie można zobaczyć rozkwit różnych charyzmatów wśród mężczyzn i kobiet ${ }^{91}$. Dlatego też w odniesieniu do naszego tematu można przyjąć założenie, że Duch Święty udzieli swoich charyzmatów wszystkim osobom, które świadomie włączą się w służbę Kościołowi. Jest to stanowisko pośrednie między zdaniem, że charyzmaty otrzymują tylko niektórzy ${ }^{92}$ a stwierdzeniem, że wszyscy chrześcijanie są charyzmatykami ${ }^{93}$.

W odniesieniu do ordo virginum, na podstawie ich obowiązków wymienionych w Obrzędach konsekracji dziewic ${ }^{94}$, można mówić o charyzmacie pokuty i modlitwy, charyzmatach czynienia miłosierdzia oraz o charyzmatach apostolstwa i posługi słowa. Wprawdzie wśród charyzmatów wymienianych przez św. Pawła ${ }^{95}$ nie mamy daru nazwanego charyzmatem pokuty i modlitwy, ale w Piśmie Świętym wielokrotnie spotykamy się z sytuacją orędowania proroka

87 Por. G. Rafiński, Pawłowe pojęcie charyzmatów, w: Duch Odnowiciel, Poznań 1998, s. 313-314 (Kolekcja Communio, 12).

${ }^{88}$ Zob. 1 Kor 14, 26.

${ }^{89}$ Zob. Ef 4, 7 .

90 Zob. Jan Paweł II, Posynodalna adhortacja apostolska o powołaniu i misji świeckich w Kościele i w świecie dwadzieścia lat po Soborze Watykańskim II Christifideles laici [dalej: ChL], nr 24, https://www.vatican.va/content/john-paul-ii/pl/apost_exhortations/documents/hf_jpii_exh_30121988_christifideles-laici.html (14.06.2021).

${ }^{11}$ Zob. ChL 24.

${ }_{92}$ Por. G. Rafiński, Pawłowe pojęcie charyzmatów, dz. cyt., s. 313.

93 Por. H. Küng, Charyzmatyczna struktura Kościoła, „Concilium” 1-10 (1965/66), s. 291.

94 Obrzędy konsekracji konsekrowanych, dz. cyt., nr 2.

${ }_{95}$ Zob. Rz 12, 6-8; 1 Kor 12, 8-11. 28-29; Ef 4, 11. 
za poszczególnymi osobami lub ludem ${ }^{96}$. Modlitwa taka może być zanoszona w Duchu Świętym ${ }^{97}$, który wychowuje Kościół do życia modlitwy ${ }^{98}$. Wydaje się, że gorliwa modlitwa jest pierwszym i podstawowym obowiązkiem osób poświęconych Bogu. $\mathrm{Z}$ modlitwy powinno wynikać wszelkie zaangażowanie w dzieła miłosierdzia czy apostolstwo. Jednakże niektóre konsekrowane mogą rozpoznawać u siebie charyzmat modlitwy, który będzie u nich na pierwszym miejscu. Zwłaszcza odprawianie liturgii godzin, w myśl duchowości monastycznej, można uważać za specyficzny charyzmat, mocą którego Duch Święty buduje Kościół ${ }^{99}$. Można w tym przypadku mówić o charyzmacie modlitwy, w tym modlitwy wstawienniczej.

Charyzmaty związane z dziełami miłosierdzia służą wypełnianiu charytatywnej funkcji Kościoła, która jest działalnością dobroczynną wynikającą z miłości, adekwatną do potrzeb ludzi doświadczających materialnego lub duchowego ubóstwa ${ }^{100}$. Wśród charyzmatów związanych z czynieniem miłosierdzia można wymienić: dar okazywania miłosierdzia, dar usługiwania, dar dawania, dar gościnności. Konsekrowana może w sposób stały służyć tymi darami w swojej bezpośredniej posłudze kościelnej w parafii lub w diecezjalnych strukturach Caritasu. Postawa miłosierdzia powinna bowiem cechować każdego chrześcijanina i nie ograniczać się jedynie do osób bezpośrednio zaangażowanych w posługę potrzebującym.

Kolejnymi darami duchowymi, którymi konsekrowana może służyć Kościołowi diecezjalnemu, są charyzmaty związane $z$ apostolstwem i posługą słowa. Przez apostolstwo osób konsekrowanych określa się świadectwo radykalnego życia chrześcijańskiego, ożywione modlitwą i pokutą ${ }^{101}$, polegające na byciu znakiem obecności Bożej w świecie, dążeniu przez miłość i służbę do powszechnego braterstwa oraz na głoszeniu słowem i życiem pierwszeństwa Boga i dóbr przyszłych nad dobrami tego świata ${ }^{102}$. Do najważniejszych

${ }_{96}$ Zob. Rdz 18, 16-33; 20, 7. 17; 25, 21; Wj 17, 8-13; 32, 32; Lb 14, 13-20; 21, 7; Sdz 21, 1-3; 1 Sm 7, 5-9; 15, 10-11; 1 Krl 13, 6; Iz 62, 6; Dn 9, 3-21.

97 Zob. Rz 8, 26.

${ }^{98}$ Zob. KKK 2623.

99 Por. Dyrektorium Służby Bożej, nr 14, w: Monastyczna liturgia godzin, t. 1: Okres Adwentu. Okres Narodzenia Pańskiego, b.m.w., 1985, s. 13-45.

${ }^{100}$ Por. W. Przygoda, Charytatywna funkcja Kościoła, w: Leksykon teologii pastoralnej, red. M. Fiałkowski, R. Kamiński, W. Przygoda, Lublin 2006, s. 130.

${ }^{101}$ Zob. KPK, kan. 673.

${ }^{102}$ Por. W. Przygoda, Apostolstwo osób konsekrowanych, w: Leksykon teologii pastoralnej, dz. cyt., s. 67. 
form apostolstwa osób konsekrowanych należą: apostolskie świadectwo życia, apostolat własny instytutu oraz apostolstwo zlecone przez hierarchię ${ }^{103}$. Konsekrowana przede wszystkim powinna dawać apostolskie świadectwo życia, które jest przeniknięte duchem Ewangelii. Może włączyć się również $\mathrm{w}$ posługę słowa, gdy jest do tego odpowiednio przygotowana. Apostolstwo prowadzone przez dziewice konsekrowane jest ściśle związane $\mathrm{z}$ ich formacją i wykształceniem (często teologicznym). Wynika z przygotowania i zależy od osobistych uwarunkowań. Wśród konsekrowanych są katechet$\mathrm{ki}$, pracownicy mediów katolickich, osoby z doktoratami z teologii, koordynatorzy szkół ewangelizacji. Mogą one we właściwy sobie sposób brać udział w szeroko rozumianym apostolstwie Kościoła we współpracy z tymi, którzy mają w Kościele władzę święceń. To apostolstwo musi odbywać się w sposób uzgodniony, koordynowany i potwierdzony przez biskupa diecezjalnego. Takie apostolstwo konsekrowanej będzie łączyło apostolat własny $\mathrm{z}$ apostolstwem zleconym przez hierarchię. Wśród charyzmatów związanych $\mathrm{z}$ apostolstwem i posługą słowa można wymienić: dar nauczania, dar ewangelizacji i dar zachęcania.

Warto również wspomnieć o trzech darach, którymi może być obdarzona konsekrowana, a które przydatne są zarówno przy charyzmatach związanych $\mathrm{z}$ czynieniem miłosierdzia, jak i charyzmatach związanych $\mathrm{z}$ apostolstwem. Chodzi o dar niesienia pomocy ${ }^{104}$, dar przewodzenia i dar administrowania. Warto zwrócić uwagę na to, że stan konsekrowanych, należący do indywidualnych form życia konsekrowanego, zakłada pełną autonomię każdej konsekrowanej. Wśród nich nie ma przełożonych, wyznaczających innym konsekrowanym kierunki działania. Jednakże niektóre z nich mogą posiadać dar przewodzenia, który będzie się uzewnętrzniał w ich miejscu pracy i posłudze kościelnej, a nie w odniesieniu do życia i posługi innych konsekrowanych.

Wśród charyzmatów, które nie były wymienione przez św. Pawła, a które są obecne w Kościele i którymi mogą posługiwać konsekrowane podczas liturgii, są dary związane z następującymi funkcjami: funkcją lektora, funkcją psałterzysty, funkcją komentatora, funkcją nadzwyczajnego szafarza Komunii świętej, funkcjami śpiewu (kantora i dyrygenta chóru, organisty, chórzysty), funkcją

${ }^{103}$ Por. W. Przygoda, Apostolstwo osób konsekrowanych, dz. cyt., s. 68.

${ }^{104} 1$ Kor 12, 28-29. Ten charyzmat jest bardzo potrzebny świeckim posługującym w Kościele, którzy są współpracownikami duchownych w posłudze słowa czy innych posługach związanych z liturgią lub dziełami miłosierdzia, w czasie których świeccy mogą wykonywać przydzielone im zadania we współpracy z prezbiterami. 
zbierającego składkę, funkcją zakrystiana ${ }^{105}$ oraz sprzątających i dekorujących kościół (charyzmat usługiwania) ${ }^{106}$.

Posługiwanie charyzmatami wymaga przygotowania. Najwyraźniej to widać przy posłudze słowa. Dar nauczania i dar ewangelizacji winien mieć podbudowę studiów teologicznych, dlatego też osoba, która dostrzega w sobie któryś $\mathrm{z}$ tych darów i chce nimi posługiwać, powinna ukończyć stosowne studia. Również rozwijanie charyzmatu lektora czy komentatora liturgicznego wymaga odpowiedniej formacji ${ }^{107}$. Poza tym ważne jest permanentne rozwijanie charyzmatów przez refleksję nad ich specyfiką, stałe poznawanie dziedzin z nimi związanych, jak i pogłębianie osobistej więzi z Chrystusem. Temu celowi służy czytanie Pisma Świętego. Zagadnienia związane z charyzmatami mają swoje podstawy biblijne, dlatego warto czytać odpowiednie teksty biblijne, które ukierunkują kościelną posługę, by mieć podbudowę teologiczną dla swojego praktycznego działania ${ }^{108}$. Niejednokrotnie do prowadzącego formację będzie należało wskazanie kandydatce odpowiednich sigli biblijnych. W odniesieniu do tekstów biblijnych wszystkie kandydatki powinny poznać zagadnienia dotyczące proroków $\mathrm{i}$ - w zależności od własnych charyzmatów - teksty biblijne o głoszeniu Ewangelii (charyzmaty związane z nauczaniem i apostolstwem), teksty biblijne o pełnieniu dzieł miłosierdzia (charyzmaty związane z dziełami miłosierdzia) czy teksty o modlitwie wstawienniczej (charyzmat pokuty i modlitwy).

\subsection{Ostateczne rozeznanie (skrutynium)}

Ostatni etap formacji początkowej polega na przygotowaniu kandydatki do obrzędu konsekracji dziewic oraz jej spotkaniu z biskupem diecezjalnym przed konsekracją. Niezwykle ważne jest zapoznanie się kandydatki z Obrzędami

${ }^{105}$ Zakrystian pełni funkcję liturgiczną. Do niego należy staranne przygotowanie ksiąg liturgicznych, szat i innych przedmiotów koniecznych w celebracji mszy świętej - zob. Ogólne wprowadzenie do Mszału rzymskiego, Rzym 2002, nr 105.

${ }^{106}$ Por. Kor 12, 5; Rz 12, 7.

${ }^{107}$ Por. B. Stypułkowska, Przygotowanie dorosłych do posługi lektora $w$ ramach katechezy biblijnej, w: Teologiczne refleksje wokół tajemnicy wiary, red. R. Ceglarek, P. Maciaszek, Częstochowa 2020, s. 105-116; B. Stypułkowska, Rola komentatora liturgicznego $w$ ramach posługi słowa i jego formacja biblijna, „Ruch Biblijny i Liturgiczny” 73 (2020) nr 4, s. 309-322.

${ }^{108} \mathrm{~W}$ tym celu warto zaproponować kandydatkom pracę według indywidualnego projektu biblijnego - zob. B. Stypułkowska, Formy i metody nauczania $w$ biblijnej katechezie dorostych, w: Katechetyk i wychowawca. Księga jubileuszowa dedykowana Ks. prof. Kazimierzowi Misiaszkowi SDB, Warszawa 2019, s. 141-158. 
konsekracji konsekrowanych. Dobrze jest, by kandydatka posiadała tekst tych obrzędów i mogła do nich wracać już w ramach formacji stałej. Zapoznanie się z homilią, modlitwą konsekracyjną i innymi częściami obrzędów może stać się duchowym przygotowaniem kandydatki do uroczystości. Jeżeli kandydatka będzie jedyną osobą konsekrowaną, może uzupełnić litanię świętych o swoich szczególnych patronów. Ważne jest też przećwiczenie uroczystości w miejscu jej odbywania się, by podczas obrzędu kandydatka nie była zbytnio zajęta szczegółami zewnętrznymi i znała przebieg uroczystości oraz uwarunkowania zewnętrzne.

$\mathrm{W}$ fazie ostatecznego rozeznania ma miejsce rozmowa duszpasterska $\mathrm{z}$ biskupem diecezjalnym, który udziela konsekracji. Kandydatka powinna odpowiednio się przygotować do tej rozmowy. Jest wtedy miejsce na przedstawienie swego sposobu życia, zaangażowania w Kościele i zarysowania perspektyw dalszej służby. Biskup diecezjalny powinien weryfikować charyzmaty i potwierdzać zaangażowanie kandydatki przed konsekracją, jak i w jej późniejszym życiu. Pytaniem otwartym pozostaje forma tej weryfikacji. Wydaje się, że pierwsza weryfikacja powinna być dokonana osobiście przez biskupa w czasie rozmowy przed konsekracją, w czasie której dopuszcza on kandydatkę do obrzędu. Następnie w kolejnych latach w większości przypadków weryfikacja życia i posługi konsekrowanej może dokonywać się przez wyznaczonego do opieki nad konsekrowanymi prezbitera. Jeżeli w diecezji istnieje praktyka sporządzania statutu personalnego ${ }^{109}$, wówczas przed konsekracją kandydatka winna uzyskać jego zatwierdzenie przez biskupa diecezjalnego. Modyfikacje statutu personalnego w trakcie życia i posługi konsekrowanej mogą być zatwierdzane przez opiekuna konsekrowanych w przypadku, gdy nieznacznie różnią się od pierwowzoru.

\section{Formacja stała}

Formacja stała obejmuje dwa okresy życia: okres pierwszy, w którym konsekrowana jest $w$ sile wieku i jest czynna zawodowo, oraz okres drugi, w którym konsekrowana jest $\mathrm{w}$ podeszłym wieku. $\mathrm{W}$ tym pierwszym okresie konsekrowana jest zaangażowana w posługę Kościołowi w „,pełnym” wymiarze, zwłaszcza, gdy

\footnotetext{
${ }^{109}$ Praktyka sporządzania statutu personalnego istnieje w odniesieniu do pustelników. Proponowana jest również w odniesieniu do dziewic konsekrowanych. Sprawa ta była poruszana na spotkaniu Podkomisji KEP ds. IFŻK we Wrocławiu 21 kwietnia 2018 roku - zob. www.ifzk. episkopat.pl/dokumenty/wroclaw_2018.pdf (11.02.2019).
} 
chodzi o głoszenie słowa Bożego czy dzieła miłosierdzia. Natomiast w miarę upływu lat i sił konsekrowana coraz bardziej przechodzi z życia czynnego w życie ukryte, oddane pokucie i modlitwie ${ }^{110}$. W okresie starości treści formacyjne będą się zmieniały, ponieważ winny obejmować zagadnienia dotyczące podeszłego wieku, w którym konsekrowane nadal uczestniczą w budowaniu Kościoła i przygotowują się na spotkanie z Chrystusem-Oblubieńcem w chwili śmierci, zwłaszcza przez doświadczenie choroby i cierpienia. Choroba i cierpienie, w których konsekrowana może łączyć się z Chrystusem cierpiącym i innymi członkami Kościoła uczestniczącymi w męce Pana ${ }^{111}$, mogą dla konsekrowanej stać się realizacją jej służby w Kościele. Warto tutaj wspomnieć o wartości doświadczenia życiowego, $\mathrm{z}$ którym konsekrowane w podeszłym wieku mogą dzielić się z kandydatkami i młodszymi konsekrowanymi. Formacja powinna przygotować konsekrowane do pogodnego zaakceptowania ograniczeń wynikających z wieku i wycofania się z czynnego życia zawodowego ${ }^{112}$.

Zadanie konsekrowanej na etapie formacji stałej polega na realizacji swojego powołania w ordo virginum przez pogłębianie więzi z Chrystusem-Oblubieńcem oraz służenie swoimi charyzmatami wspólnocie Kościoła i stałym rozeznawaniu swojego zaangażowania. Zadania innych odpowiedzialnych za formację w ordo virginum związane są z towarzyszeniem jej w życiu i posłudze. Zadanie kierownika duchowego polega na udzieleniu pomocy konsekrowanej w rozeznawaniu jej zaangażowania w służbę Kościołowi ${ }^{113}$ oraz na weryfikowaniu jej sposobu życia i posługi. Nie zawsze jednak kierownik duchowy będzie zorientowany w specyfice indywidualnych form życia konsekrowanego, w tym w specyfice życia ordo virginum, dlatego powinna być też możliwa jakaś inna forma weryfikacji życia konsekrowanej. Wydaje się,

${ }^{110}$ Przy formacji początkowej była mowa o tym, że niektóre konsekrowane od początku mogą rozeznawać u siebie taki charakter życia ukrytego. Przykładem biblijnym osoby poświęconej Bogu w podeszłym wieku jest prorokini Anna - zob. Łk 2, 36-38.

${ }^{111}$ Zob. Kol 1, 24. Por. uwagi Jana Pawła II odnoszące się do formacji stałej starszych kapłanów w PDV 77.

${ }^{112}$ Por. B. Giordani, Formacja kobiet konsekrowanych. Wskazówki psychologiczno-pedagogiczne, przeł. B. Rzepka, Kraków 2007, s. 112. Na temat okresu starości zob. H. Słotwińska, Starość wkraczaniem w ostatni etap dojrzewania do eschatologii, „Roczniki Teologiczne” 65 (2018) z. 11, s. 205-226.

${ }^{113}$ Kierownik duchowy dokonuje pierwszego rozpoznania dotyczącego ewentualnej posługi konsekrowanej. Kolejne kroki należą do przełożonych, którzy są odpowiedzialni za konkretne dzieła w diecezji, lub proboszcza, gdy rzecz dotyczy posługi w parafii. Niekiedy realizacja inicjatywy konsekrowanej będzie wymagała zgody biskupa diecezjalnego. Wówczas jego podejście do przedstawionej sprawy będzie dla konsekrowanej najlepszą pomocą przy rozeznawaniu. 
że opiekun konsekrowanych mógłby dokonywać tej weryfikacji, niekoniecznie pełniąc rolę spowiednika czy kierownika duchowego i nie wchodząc w zakres ich kompetencji. Poza tym zadanie opiekuna konsekrowanych polega na udzielaniu pomocy konsekrowanej w zakresie jej formacji stałej oraz interweniowania w zakresie wykonywania posługi kościelnej, gdy zajdzie taka potrzeba.

Treści kształcenia w formacji stałej można ująć w dwóch punktach: pogłębianie więzi z Chrystusem-Oblubieńcem przez udział w liturgii roku kościelnego ${ }^{114}$ oraz uwrażliwienie na sposób wypełniania posługi w Kościele. Aspekt chrystocentryczny formacji będzie dotyczył więzi z Chrystusem, której pogłębienie dokonuje się podczas liturgii, natomiast aspekt eklezjalny dotyczący służby w Kościele, będzie wynikał z troski konsekrowanej, by „troszczyć się o sprawy Pana"115.

\subsection{Aspekt chrystocentryczny w formacji stałej}

Formacja teologiczna ma doprowadzić do spotkania z Chrystusem w liturgii i słowie Bożym. Spotkanie z Chrystusem-Oblubieńcem dokonuje się podczas liturgii, w której Duch Święty jest wychowawcą ${ }^{116}$. Przygotowanie do liturgii i uczestniczenie w niej wymaga uwagi i świadomości, które zdobywa się przez doświadczenie. Niemniej jednak wykłady, konferencje i lektury mogą być przyczynkiem do dobrego przygotowania. W formacji stałej konsekrowanych żyjących w świecie przydatna może okazać się duchowość monastyczna ${ }^{117}$. Duchowość monastyczną można nazwać duchowością długodystansowca, która pomimo pozornego braku natychmiastowych rezultatów daje bardzo mocne fundamenty dla budowli ludzkiego życia i przydatna jest zwłaszcza w odniesieniu do formacji stałej. Na przestrzeni wieków wokół wielkich ośrodków monastycznych wykrystalizowały się praktyki mające pomóc w duchowym wzroście, niebędące jednak ograniczającym zbiorem sztywnych przepisów, ale raczej skarbcem, $\mathrm{z}$ którego czerpie się to, czego potrzeba do rozwoju życia duchowego. Może to być przydatne dla konsekrowanych żyjących w świecie. Chodzi tu przede wszystkim o mszę świętą, liturgię godzin, lectio divina, lekturę

${ }^{114}$ Warto zauważyć, że rok liturgiczny został określony jako główna droga dla dziewic konsekrowanych, które po niej podążają wspólnie z innymi na spotkanie z Chrystusem-Oblubieńcem zob. ESI 31.

${ }^{115}$ Por. 1 Kor 7, 34.

${ }^{116}$ Zob. KKK 1091.

${ }^{117}$ Por. B. Stypułkowska, Perspektywy dla dziewic konsekrowanych żyjących w świecie wynikające $z$ duchowości monastycznej, dz. cyt., s. 195-222. 
duchową oraz modlitwę osobistą (tzw. modlitwę wewnętrzną). Powyższe praktyki życia duchowego nie są zbiorem oderwanych od siebie pojedynczych aktów, wypełnianych w określonym czasie, ale raczej sumą przenikających się wzajemnie składników, które zapewniają mnichowi, a zarazem i konsekrowanej, wszelkie środki potrzebne do otwierania się na działanie Boga, co jest zasadniczym celem ich życia ${ }^{118}$. Proces formacji stałej rozkłada się na całe życie człowieka, dlatego ważne jest wypracowanie przez konsekrowaną własnego rytmu formacji, który będzie obejmował cykl dzienny, tygodniowy, miesięczny i roczny ${ }^{11}$. W powołaniu pustelniczym rytm formacji określony jest przez indywidualny statut personalny. W odniesieniu do konsekrowanych statut personalny sporządzony przez kandydatkę przed konsekracją i zatwierdzony przez biskupa mógłby być uzupełniony o aneks, w którym konsekrowana zamieści szczegółowe dane dotyczące jej własnego rytmu formacyjnego: rytmu dnia, tygodnia, miesiąca i roku ${ }^{120}$.

${ }^{118}$ Por. Duchowość monastyczna dla człowieka żyjącego w świecie, http://ps-po.pl/2017/o9/o1/ duchowosc-monastyczna-dla-czlowieka-zyjacego-w-swiecie/ (1.09.2017).

${ }^{119}$ Por. A. Cencini, Oddech życia. Łaska formacji permanentnej, przeł. J. Zarzycka, Kraków 2004, s. 57. Już na etapie formacji początkowej ważne jest nadawanie stałej formy swoim praktykom religijnym i rozwijanie umiejętności zarządzania rytmem dnia, tygodnia i roku - zob. ESI 99.

${ }^{120}$ Aneks ze względu na swój mniej oficjalny charakter może być zatwierdzany przez kierownika duchowego i częściej zmieniany niż sam statut personalny. Gdy chodzi o plan dnia, tutaj szczególną uwagę należy zwrócić na czas i miejsce codziennej modlitwy prywatnej i liturgicznej, w tym również przygotowanie się do Eucharystii i własne studium. Wyrobienie nawyków związanych z modlitwą winno dokonywać się już podczas formacji początkowej, a modlitwa musi harmonizować z pracą i odpoczynkiem. Ważne jest dokonywanie codziennego rozliczenia, które pozwala na przeżywanie codzienności w sposób bardziej świadomy. Rytm tygodniowy zwraca uwagę na niedzielę - pierwszy dzień tygodnia i dzień Zmartwychwstania Chrystusa. Może być ona przeżywana przez konsekrowaną jako czas budowania relacji z Oblubieńcem w atmosferze święta i odpoczynku. Kolejne dni tygodnia mogą być przez konsekrowaną powiązane z przeżywaniem określonych tajemnic związanych z Chrystusem. Rytm miesięczny wyznaczony jest przez przystępowanie do sakramentu pokuty i pojednania, który daje sposobność do refleksji nad wypełnianiem przykazania miłości Boga i bliźniego oraz rozliczenia się z podejmowanych postanowień. Pożyteczne jest przeznaczenie pewnego czasu raz w miesiącu na dokonanie podsumowania swoich działań i zaplanowanie najbliższych tygodni (np. w ostatnim dniu miesiąca). Ponadto wskazane jest wybranie drugiego dnia w miesiącu na refleksję nad tajemnicą konsekracji. Może być na to wyznaczony dzień „miesięcznicy” konsekracji, w czasie którego konsekrowana znajdzie czas na lekturę obrzędów konsekracji, encykliki Jana Pawła II Vita consecrata, instrukcji Ecclesia Sponsae Imago czy innych pozycji związanych z formacją osób konsekrowanych. Rytm roczny wyznaczony jest przez rok liturgiczny i trzy wielkie święta kościelne: Boże Narodzenie z poprzedzającym je Adwentem, Wielkanoc z poprzedzającym ją Wielkim Postem oraz Pięćdziesiątnicą z poprzedzającym ją Okresem 
Pogłębianie więzi z Chrystusem będzie dokonywało się przede wszystkim w osobistej modlitwie osoby konsekrowanej. Związane jest też z poznawaniem Chrystusa w Piśmie Świętym, i w tym mogą pomóc formatorzy. Jako osoba zaślubiona Jezusowi Chrystusowi, dziewica konsekrowana powinna dążyć do tego, by tworzyć z Nim „jedno ciało”, jak może sugerować tekst św. Pawła charakteryzujący małżeństwo ${ }^{121}$. U św. Pawła być „w Chrystusie”122 oznacza to samo, co być w „W Duchu”23. Działalność konsekrowanej powinna być współdziałaniem z Duchem Świętym. Można się tego uczyć przez lectio divina, bowiem przez czytanie i rozważanie Pisma Świętego konsekrowana będzie napełniała się Duchem Świętym. Treści przekazywane podczas formacji stałej powinny zatem dotyczyć zagadnień biblijnych, które pomogą konsekrowanej zrozumieć słowo Boże.

Aspekt chrystocentryczny formacji jest ściśle związany $\mathrm{z}$ aspektem eklezjalnym. Biblijne obrazy Kościoła (Oblubienica Chrystusa $^{124}$, Krzew winny i latorośle ${ }^{125}$, Ciało Chrystusa ${ }^{126}$, owczarnia Pańska $^{127}$, budowla Boża ${ }^{128}$, świątynia Ducha Świętego ${ }^{129}$, lud Boży ${ }^{130}$, rodzina

wielkanocnym łączącym Paschę Chrystusa z Zesłaniem Ducha Świętego. W Adwencie i w czasie Bożego Narodzenia konsekrowana może pogłębiać zrozumienie tajemnicy przychodzącego Chrystusa-Oblubieńca oraz rzeczywistość konsekracji. W Wielkim Poście i podczas Triduum Paschalnego konsekrowana może pogłębiać zrozumienie tajemnicy Chrystusa-Odkupiciela oraz rzeczywistości sakramentu chrztu i Eucharystii. W czasie Okresu wielkanocnego i Pięćdziesiątnicy konsekrowana może pogłębiać tajemnicę Chrystusa posyłającego oraz rzeczywistości sakramentu bierzmowania. Dobre przeżywanie liturgii może stanowić podstawowy program formacji stałej. W rytmie rocznym przewidziany jest czas na rekolekcje. Mogą to być rekolekcje stanowe, w czasie których konsekrowana będzie mogła zastanowić się nad własną tożsamością, lub rekolekcje związane z przeżywaną przez nią duchowością. Rekolekcje konsekrowana może przeżywać indywidualnie, sama dobierając sobie lekturę. Jednakże raz na jakiś czas dobrze jest uczestniczyć w rekolekcjach prowadzonych przez innych.

${ }^{121}$ Zob. Ef 5, 32.

${ }^{122} \mathrm{Rz} 8,1$.

${ }^{123} \mathrm{Rz} 8$, 9; por. G. S. Hendry, Duch Święty, w: Słownik wiedzy biblijnej, red. naukowa B. M. Metzger, M. D. Coogan, konsultacja wyd. polskiego W. Chrostowski, Warszawa 1996, s. 123; J. Guillet, Duch Boży, dz. cyt., s. 233; T. Paige, Duch Święty, dz. cyt., s. 161-162.

${ }^{124}$ Zob. Ef 5, 25; Ap 21, 2; 22, 17.

${ }_{125}$ Zob. J 15, 1-8.

${ }^{126}$ Zob. 1 Kor 12, 12-30; Rz 12, 4-5; Ef 1, 22-23; Kol 1, 18. 24.

${ }^{127}$ Zob. J 10, 1-17.

${ }^{128}$ Zob. 1 P 2, 5.

${ }^{129}$ Zob. 1 Kor 3, 16; 6, 19.

${ }^{130}$ Zob. 1 P 2, 20; Rz 9, 25. 
Boża ${ }^{131}$ ) wskazują na konieczność duchowości komunii z Chrystusem i innymi członkami Kościoła. Podczas Eucharystii Duch Święty buduje Kościół, tworzy jedno Ciało zgromadzonych wokół Chrystusa. Dlatego formacja konsekrowanych winna szczególną wagę przykładać do coraz głębszego uczestnictwa w liturgii Kościoła, zwłaszcza w Eucharystii i liturgii godzin. Eucharystia może być przeżywana jako uczta godowa Baranka, a liturgia godzin jako wspólny głos Oblubieńca i Oblubienicy. Cenne w formacji konsekrowanych są teksty biblijne, które ukazują Boga jako Oblubieńca i Kościół jako Oblubienicę $e^{132}$.

\subsection{Aspekt eklezjalny w formacji stałej}

Formacja teologiczna w odniesieniu do aspektu eklezjalnego powinna dotyczyć „tu i teraz” Kościoła diecezjalnego, z czym związane są treści dotyczące bieżących inicjatyw duszpasterskich, nauczania i wskazań biskupa diecezjalnego ${ }^{133}$. Aktywna obecność kobiety w Kościele i jej działalność duszpasterska może wzbogacić sposób przeżywania rzeczywistości duchowej ${ }^{134}$. W działalności duszpasterskiej i w formacji religijnej kobieta będzie bardziej świadomie niż mężczyzna wchodziła w relacje interpersonalne, koncentrując się na osobach, którym służy, a nie na samym działaniu. Do refleksji teologicznej kobieta również może wnieść cenny wkład. Nie chodzi przy tym o wypracowanie teologii na temat kobiety, lecz o teologię pisaną przez kobiety i odnoszącą się do wszystkich dziedzin, na jakie rozciągają się nauki teologiczne. Dlatego ważne jest to, by kobiety angażowały się w studiowanie i nauczanie teologii, a jeszcze bardziej w przekazywanie słowa Bożego, pisanego i mówionego ${ }^{135}$. W odniesieniu do zaangażowania konsekrowanej w posługę Kościołowi warto zaznaczyć,

${ }^{131}$ Zob. Ef 2, 19-22.

${ }^{132}$ Można tutaj skorzystać z propozycji tekstów biblijnych dla katechezy powołaniowej skierowanej do dziewcząt - zob. B. Stypułkowska, Biblijna katecheza powołaniowa ze szczególnym uwzględnieniem dziewcząt, „Sosnowieckie Studia Teologiczne” 14 (2018/2019), s. 387-406.

${ }^{133} \mathrm{~W}$ formacji przed konsekracją zalecane jest zdobycie odpowiedniej wiedzy na temat historii Kościoła lokalnego, jego instytucji, tradycji duchowych, wyborów duszpasterskich i doświadczeń profetycznych w nim obecnych, a także trudności, z jakimi się zmaga i ran, które są przyczyną cierpienia - zob. ESI 10o. Ze względu na zaangażowanie konsekrowanej w konkretnym Kościele diecezjalnym warto uwzględnić również w formacji stałej te treści. Konsekrowane mogą brać udział w pielgrzymkach do miejsc świętych w diecezji i uczestniczyć w katedralnych uroczystościach. Treści dotyczące Kościoła partykularnego mogą być przekazywane w ramach ogólnych spotkań wszystkich osób konsekrowanych w diecezji, na które będą zapraszane również dziewice.

${ }^{134}$ Por. B. Giordani, Wybrane przez Chrystusa, dz. cyt., s. 52.

${ }^{135}$ Por. B. Giordani, Wybrane przez Chrystusa, dz. cyt., s. 52-53. 
że specyfiką kobiety jest „być”, a nie „działać” ${ }^{136}$, dlatego też i jej posługa ma charakter zasadniczo wewnętrzny, polegający na byciu znakiem oblubienicy-Kościoła, która kocha Chrystusa niepodzielną miłością. Wprawdzie miłość ta przejawia się w zewnętrznym zaangażowaniu, jednakże jej istota jest ukryta, w myśl stwierdzenia św. Pawła, że nasze życie jest ukryte z Chrystusem w Bogu ${ }^{137}$, i w związku z tym konsekrowana powinna przede wszystkim w formacji zwrócić uwagę na rozwijanie życia duchowego, a nie na zaangażowanie zewnętrzne. Święty Paweł scharakteryzował dziewicę jako tę, która troszczy się o sprawy Pana $^{138}$. Kobieta musi dbać o to, by właściwie ustawić priorytety, odróżniać sprawy ważne od mniej ważnych i koncentrować się na tym, co istotne. Wiąże się z tym przeznaczanie odpowiedniego czasu na modlitwę i studium, rezygnowanie z niepotrzebnych spotkań i rozmów, które niczego nie wnoszą do życia duchowego, a także właściwe dobieranie intencji modlitewnych, by obejmować swą modlitwą rzeczywiste potrzeby diecezji i wspierać biskupa. Apostoł Narodów przestrzega wdowy przed rozgadaniem, wścibstwem, rozprawianiem o rzeczach niepotrzebnych ${ }^{139}$. Dotyczy to wszystkich, nie tylko wdów. Dla konsekrowanej ważne jest poza tym rozwijanie charyzmatu kobiety, który polega na wnoszeniu w struktury kościelne tego, co jest charakterystyczne dla kobiecej wrażliwości: ukierunkowanie na osoby i związana z tym empatia, dostrzeganie potrzeb, budowanie głębszych relacji oraz towarzyszenie przez modlitwę wstawienniczą. Kobieca wrażliwość bliska jest oddziaływaniu Ducha Świętego, dlatego też najpełniej wyraża się przez Jego owoce. Święty Paweł stosuje wyrażenie „Owoc Ducha” ${ }^{140}$ do opisu cnót, które ujawniają rzeczywistość życia w Chrystu-

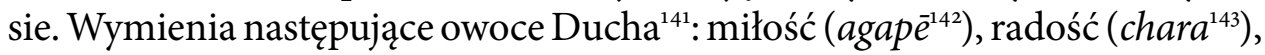

\footnotetext{
${ }^{136}$ Por. B. Giordani, Wybrane przez Chrystusa, dz. cyt., s. 40.

137 Zob. Kol 3, 3.

${ }^{138}$ Zob. 1 Kor 7, 34.

139 Zob. 1 Tm 5, 13.

${ }^{140} \mathrm{Ga}$ 5, 22-23; por. D. S. Dockery, Owoc Ducha, w: Słownik teologii św. Pawła, dz. cyt., s. 559.

${ }^{141}$ Zob. Ga 5, 22-23; Grecko-polski Nowy Testament. Wydanie interlinearne z kodami gramatycznymi,
} tłum. R. Popowski, M. Wojciechowski, Warszawa 1994, s. 900.

${ }^{142}$ Zob. J. Strong, Grecko-polski słownik Stronga z lokalizacją słów greckich i kodami Popowskiego, Warszawa 2015, s. 5; R. Popowski, Wielki słownik grecko-polski Nowego Testamentu, dz. cyt., s. 3-4; o miłości do ludzi przez Osoby Boskie: J 15, 9. 10. 13; Rz 5, 5. 8; 8, 35. 39; 2 Kor 5, 14; 13, 11. 13; Ef 1, 4; 2, 4; 3, 19; 1 J 3, 1. 16; 4, 7. 8. 9. 10. 16; o miłości do bliźnich: J 13, 35; Rz 13, 10; 16, 24; 1 Kor 16, 24; 2 Kor 2, 4. 8; 8, 7; Ef 1, 15; Kol 1, 4; 1 Tes 3, 12; 2 Tes 1, 3; 1 P 4, 8.

${ }^{143}$ Zob. J. Strong, Grecko-polski słownik Stronga z lokalizacją słów greckich i kodami Popowskiego, dz. cyt., s. 827; R. Popowski, Wielki słownik grecko-polski Nowego Testamentu, dz. cyt., s. 650; Mt 2, 10;13, 20. 44; 25, 21. 23; 28, 8; Mk 4, 16; Łk 1, 14; 2, 10; 8, 13; 10, 17; 15, 7. 10; 24, 41. 52; J 3, 29; 15, 11; 
pokój (eirēnē $\left.{ }^{-144}\right)$, cierpliwość (makrothymia $\left.{ }^{145}\right)$, uprzejmość (chrēstotēe $\left.{ }^{146}\right)$, dobroć (agathōsyne $\left.{ }^{-147}\right)$, wierność (pistis ${ }^{148}$ ), łagodność (prautēs ${ }^{149}$ ), opanowanie $\left(\right.$ enkrateia $\left.{ }^{150}\right)$. Agapē oznacza miłość w sensie takiej postawy, jaką ma Bóg wobec ludzi; dobrą wolę; życzliwość w sensie decyzyjnym, a nie emocjonalnym; jest to postawa świadczenia dobra komuś, kto na to dobro nie zasługuje. Eirēnē oznacza pokój, zgodę, bezpieczeństwo, harmonię, pokój między poszczególnymi ludźmi. Według Dobrej Nowiny eirēnē jest to stan relacji między Bogiem a wierzącym, w którym ten ostatni jest pewny swego zbawienia w Chrystusie; błogosławiony stan, do jakiego zostaną wprowadzeni ci, którzy złożyli w Chrystusie swoje zaufanie i w Nim wytrwali. Pokój jest darem Ojca, danym przez Syna. W Nowym Testamencie bywa synonimem zbawienia. Według proroków pokój charakteryzuje królestwo mesjańskie. Makrothymia oznacza cierpliwość, wytrwałość, stałość, wielkoduszność, wyrozumiałość. Chrēstotēs jest to uprzejmość, szlachetność, dobroć moralna, prawość, dobrotliwość, łagodność. Agathōsynē oznacza dobroć, życzliwość, prawość serca i życia.

16, 20. 21. 22. 24; 17, 13; Dz 8, 8; 12, 14; 13, 52; 15, 3; Rz 14, 17; 15, 13. 32; 2 Kor 1, 24; 2, 3; 7, 4. 13; 8, 2; Ga 5, 22; Flp 1, 4. 25; 2, 2. 29; 4, 1; Kol 1, 11; 1 Tes 1, 6; 2, 19. 20; 3, 9; 2 Tm 1, 4; Flm 1, 7; Hbr 10, 34; 12, 2. 11; 13, 17; Jk 1, 2; 4, 9; 1 P 1, 8; 1 J 1, 4; 2 J 1, 12; 3 J 1, 4.

${ }^{144}$ Zob. J. Strong, Grecko-polski słownik Stronga z lokalizacją słów greckich i kodami Popowskiego, dz. cyt., s. 229; R. Popowski, Wielki słownik grecko-polski Nowego Testamentu, dz. cyt., s. 169; Mt 10, 34; Łk 1, 79; 12, 51; 19, 42; Dz 7, 26; 9, 31; Rz 3, 17; 14, 19; Ga 5, 22; Ef 2, 15; 4, 3; 1 Tes 5, 3; 2 Tm 2, 22; Hbr 7, 2; 11, 31; 12, 14; Jk 3, 18; 1 P 3, 11; 2 P 3, 14.

${ }_{145}$ Zob. J. Strong, Grecko-polski słownik Stronga z lokalizacją słów greckich i kodami Popowskiego, dz. cyt., s. 482; R. Popowski, Wielki słownik grecko-polski Nowego Testamentu, dz. cyt., s. 375; Rz 2, 4; 9, 22; 2 Kor 6, 6; Ga 5, 22; Ef 4, 2; Kol 3, 12; 1 Tm 1, 16; 2 Tm 4, 2; Hbr 6, 12; Jk 5, $10 ; 1$ P 3, 20; 2 P 3, 15.

${ }^{146}$ Zob. J. Strong, Grecko-polski słownik Stronga z lokalizacją słów greckich i kodami Popowskiego, dz. cyt., s. 837; R. Popowski, Wielki słownik grecko-polski Nowego Testamentu, dz. cyt., s. 657; $\mathrm{Rz}$ 2, 4; 3, 12; 11, 22; 2 Kor 6, 6; Ga 5, 22; Ef 2, 7; Kol 3, 12; Tt 3, 4.

${ }^{147}$ Zob. J. Strong, Grecko-polski słownik Stronga z lokalizacją słów greckich i kodami Popowskiego, dz. cyt., s. 4; R. Popowski, Wielki słownik grecko-polski Nowego Testamentu, dz. cyt., s. 3; Rz 15, 14; Ga 5, 22; Ef 5, 9; 2 Tes 1, 11.

${ }^{148}$ Zob. J. Strong, Grecko-polski słownik Stronga z lokalizacją słów greckich i kodami Popowskiego, dz. cyt., s. 621; R. Popowski, Wielki słownik grecko-polski Nowego Testamentu, dz. cyt., s. 495-496; Mt 23, 23; Rz 3, 3; Ga 5, 22; 2 Tes 1, 4; 2 Tm 4, 7; Tt 2, 10.

${ }^{149}$ Zob. J. Strong, Grecko-polski słownik Stronga z lokalizacją słów greckich i kodami Popowskiego, dz. cyt., s. 644; R. Popowski, Wielki słownik grecko-polski Nowego Testamentu, dz. cyt., s. 519; 1 Kor 4, 21; 2 Kor 10, 1; Ga 5, 23; 6, 1; Ef 4, 2; Kol 3, 12; 2 Tm 2, 25; Tt 3, 2; Jk 1, 21; 3, 13; 1 P 3, 16.

${ }^{150}$ Zob. J. Strong, Grecko-polski słownik Stronga z lokalizacją słów greckich i kodami Popowskiego, dz. cyt., s. 221; R. Popowski, Wielki słownik grecko-polski Nowego Testamentu, dz. cyt., s. 154; Ga 5, 23; Dz 24, 25; 2 P 1, 6. 
Pistis - wierność, ufność, rzetelność, wiara, zaufanie do Boga wynikające z przekonania o prawdziwości Jego słowa. Prautēs - łagodność, delikatność, cichość, uprzejmość, skromność. Enkrateia zaś jest to opanowanie, wstrzemięźliwość, umiarkowanie, panowanie nad sobą, cnota tego, kto panuje nad swoimi pragnieniami i namiętnościami, zwłaszcza pożądaniami zmysłowymi. Wszystkie te cnoty charakteryzują człowieka duchowego. Dzięki nim w człowieku powoli formuje się Chrystus ${ }^{151}$. Owoce Ducha mają swoje bezpośrednie odniesienie do ośmiu błogosławieństw ${ }^{152}$. Konsekrowana przez swoje zachowanie i posługę ma pachnieć Oblubieńcem i roznosić woń Chrystusa-Oblubieńca ${ }^{153}$.

Wykonywanie określonej posługi w Kościele związane jest z rozeznawaniem. Chodzi o rozeznawanie woli Bożej, które jest procesem związanym z wprowadzeniem słowa Bożego w życie pod natchnieniem Ducha Świętego. W formacji indywidualnej należy zwrócić uwagę na współdziałanie konsekrowanej z Duchem Świętym. Formacja stała winna pomóc konsekrowanej w rozeznawaniu swojej służby w Kościele, która będzie zgodna z oczekiwaniami Chrystusa, jej Oblubieńca oraz w rozwijaniu swoich charyzmatów. Jan Paweł II w encyklice Vita consecrata zwraca uwagę, że osobistemu rozeznawaniu i podejmowaniu wielkich dzieł służy praktyka lectio divina, bowiem z rozważania słowa Bożego rodzi się gorliwość w apostolacie ${ }^{154}$. Dobrze jest, jeśli osoba konsekrowana swoją interpretację woli Bożej może skonsultować $\mathrm{z}$ kierownikiem duchowym ${ }^{155}$. Jednakże konsekrowana może nie mieć swojego kierownika, a pracę nad sobą

${ }^{151}$ Por. T. Paige, Duch Święty, dz. cyt., s. 164.

${ }^{152}$ Zob. Mt 5, 3-12; Łk 6, 20-23; por. A. Deneka, Duch Święty, w: Leksykon duchowości katolickiej, red. M. Chmielewski, Lublin-Kraków 2002, s. 225. Św. Augustyn połączył z błogosławieństwami dary Ducha Świętego - zob. Św. Augustyn, O kazaniu Pana na Górze, 4.11, w: Św. Augustyn, O kazaniu Pana na Górze. Do Symplicjana o różnych problemach. Problemy ewangeliczne, tłum. S. Ryznar, J. Sulowski, wstęp i oprac. E. Stanula, Warszawa 1989, s. 26-27. Życie według Ducha Świętego jest równoznaczne z życiem zgodnym z nauczaniem Chrystusa i związane z błogosławieństwami. Osiem błogosławieństw zaś wiąże się z radami ewangelicznymi. Rady ewangeliczne zostały omówione w oddzielnym artykule - zob. B. Stypułkowska, Rady ewangeliczne w życiu dziewicy konsekrowanej, dz. cyt. Wszystkie te zagadnienia powinny zostać poruszone w formacji osób konsekrowanych.

${ }^{153} \mathrm{Na}$ ten temat zob. B. Stypułkowska, Biblijna katecheza powołaniowa ze szczególnym uwzględnieniem dziewcząt, dz. cyt., s. 387-406.

${ }^{154}$ Zob. VC 94.

${ }^{155}$ Należy mieć świadomość, że u osoby korzystającej z kierownictwa duchowego może dochodzić mimowolnie do traktowania wszystkich słów kierownika jako słów pochodzących od Boga. Kierownik będzie odbierany jako symboliczny reprezentant Boga i może być istotnym pośrednikiem doświadczenia religijnego osoby kierowanej - por. J. K. Ruffing, Kierownictwo duchowe. Dalsze etapy, przekł. K. Gdowska, Kraków 2010, s. 187, 189. Wydaje się, że dla weryfikacji 
podejmuje ze stałym spowiednikiem ${ }^{156}$. Dlatego w kierownictwie duchowym należy zauważyć rolę biskupa diecezjalnego. Posługę biskupa można określić jako rozeznawanie działania Ducha Świętego, a zewnętrznym przejawem tej posługi jest wyrażenie / lub niewyrażenie zgody na realizację projektów i zamierzeń konsekrowanej ${ }^{157}$. Rola opiekuna konsekrowanych w formacji stałej jest mniejsza niż w formacji początkowej, ale nadal istotna. Jest on reprezentantem biskupa, który pomaga konsekrowanym zrealizować swoje powołanie $e^{158}$. Służba

życia i posługi konsekrowanej wskazany jest przynajmniej raz w roku kontakt konsekrowanej z jej kierownikiem duchowym, w przypadku gdy nie jest on jej stałym spowiednikiem.

${ }^{156}$ Stały spowiednik niekoniecznie musi być kierownikiem duchowym. Kierownik duchowy jest osobą, która pomaga w odczytywaniu woli Bożej przez towarzyszenie duchowe, wspieranie w zachowywaniu słowa Bożego i wprowadzaniu go w życie oraz udzielanie rad dotyczących życia duchowego. Zewnętrznym przejawem posługi kierownika duchowego jest pomoc w rozeznawaniu zaangażowania w posługę Kościołowi. Natomiast posługa stałego spowiednika polega na udzielaniu pomocy w pracy nad sobą przez dawanie wskazówek i rad dotyczących życia duchowego, a zewnętrznym przejawem jego posługi życie penitentki w łasce uświęcającej.

${ }^{157}$ Gdy chodzi o systematyczne spotkania konsekrowanej z biskupem diecezjalnym, to trudno wymagać od biskupa indywidualnych rozmów z każdą konsekrowaną, weryfikujących jej życie i posługę. Nie ma takiej praktyki nawet w odniesieniu do prezbiterów, którzy są jego najbliższymi współpracownikami. Aby jednak umożliwić konsekrowanym osobisty kontakt z biskupem, można wykorzystać do tego czas wizytacji w parafii. Biskup przeprowadza wtedy rozmowy duszpasterskie $\mathrm{z}$ różnymi osobami i wskazane jest, aby odbyła się wówczas rozmowa $\mathrm{z}$ konsekrowaną, mająca charakter weryfikacji jej życia i posługi. Ponieważ nie każdą wizytację przeprowadza biskup diecezjalny, należałoby zastanowić się nad innymi możliwościami spotkania przynajmniej raz na kilka lat, aby biskup miał informację o życiu danej konsekrowanej od niej samej. Czymś oczywistym jest przekazywanie biskupowi informacji o konsekrowanych ze strony ich opiekuna. W sytuacjach szczególnych konsekrowana może spotykać się ze swoim biskupem w czasie jego urzędowania w kurii. Jednak wówczas jest czas raczej na załatwianie konkretnych spraw związanych z posługą niż na rozmowę duszpasterską. Wyjątek stanowią rozmowy z kandydatkami przed konsekracją, o czym była mowa wyżej.

${ }^{158}$ Konsekrowana powinna mieć możliwość indywidualnego spotkania z opiekunem konsekrowanych przynajmniej raz w roku w celu przeprowadzenia rozmowy poruszającej zagadnienia związane z jej formacją i posługą na poziomie diecezji. Odpowiedzialny za formację winien upewnić się, czy konsekrowane mają możliwość uczestniczenia w rekolekcjach stanowych organizowanych przez Podkomisję KEP ds. IFŻK i ewentualnie powinien sam zorganizować takie rekolekcje lub skierować na nie do innej diecezji. W rozmowie indywidualnej opiekuna z konsekrowaną wskazane byłoby także zainteresowanie się z jego strony warunkami pełnienia posługi kościelnej w przypadku młodszych konsekrowanych oraz warunkami życia i stanem zdrowia w przypadku starszych. W sytuacjach nieprawidłowych w pierwszym przypadku winien on interweniować u pracodawcy kościelnego, a w drugim przypadku sygnalizować problem proboszczowi czy $\mathrm{w}$ diecezjalnym Caritasie. Wprawdzie każda konsekrowana sama musi zapewnić sobie utrzymanie 
w Kościele, mająca zazwyczaj charakter diecezjalny, realizuje się konkretnie w parafii, w której konsekrowana mieszka lub w instytucji kościelnej, w której pracuje. Formacja stała winna kształtować dyspozycyjność konsekrowanej wobec potrzeb diecezji, z którą może wiązać się nawet gotowość do zmiany pracy ze „świeckiej” na „kościelną”, np. w charakterze nauczyciela religii w szkole, co wymagałoby podjęcia studiów teologicznych. Ważne jest tutaj rozeznawanie na modlitwie własnego zaangażowania przez konsekrowaną. Zaangażowanie to będzie związane $\mathrm{z}$ konkretnymi osobami: biskupem diecezjalnym i proboszczem lub przełożonym w pracy. Do opiekuna konsekrowanych należy ukazanie perspektyw zaangażowania się świeckich w Kościele, ponieważ świeccy, którzy na stałe lub czasowo poświęcają się posłudze Kościoła, mają obowiązek zdobyć odpowiednią formację, potrzebną do właściwego wykonywania swego zadania, by mogli ją spełniać świadomie, umiejętnie i pilnie ${ }^{159}$.

i opiekę zdrowotną, jednak miłosierdzie chrześcijańskie wymaga, by interesować się potrzebami osób starszych i w miarę potrzeby pomagać im.

159 Zob. KPK, kan. 231 \$1. Konstytucja dogmatyczna o Kościele Soboru Watykańskiego II wskazuje, że ludzie świeccy mogą być powoływani w różny sposób do bardziej bezpośredniej współpracy z apostolatem hierarchii (LG 33; P. Neuner, P. M. Zulehner, Zrozumieć Kościót. Eklezjologia praktyczna, przeł. A. Kalbarczyk, Poznań 2016, s. 158), a kodeks prawa kanonicznego w odniesieniu do posługi słowa mówi o tym, że wierni świeccy mogą być powoływani na współpracowników biskupa i prezbiterów (KPK, kan. 759; zwykle współpracownikami biskupa są określani prezbiterzy - zob. LG 28; Kongregacja ds. Duchowieństwa, Dyrektorium o posłudze i życiu kapłanów, Poznań 2003, $\mathrm{nr}$ 47). Konsekrowana, jeżeli jest do tego odpowiednio przygotowana, może się włączyć właśnie w tę posługę (aby mieć swój udział w wykonywaniu apostolatu przez głoszenie nauki, świecki ma obowiązek poznać tę naukę w sposób dostosowany do jego możliwości i zajmowanej pozycji zob. KPK, kan. $229 \$ 1$; by nauczać religii w szkole, co jest przykładem głoszenia słowa Bożego, świecki musi posiadać misję kanoniczną, którą można otrzymać tylko po studiach teologicznych). Jeżeli natomiast nie ma wykształcenia teologicznego może przez własne inicjatywy popierać lub podtrzymywać apostolską działalność Kościoła (KPK, kan. 216), również przez wsparcie materialne, na wzór kobiet $\mathrm{z}$ Ewangelii, które usługiwały Chrystusowi i Dwunastu ze swego mienia (Łk 8, 1-3; Mk 15, 40-41; Mt 27, 55-56). Konsekrowane mogą być zawodowo zaangażowane w różnych instytucjach diecezjalnych jako pracownicy administracyjni, socjalni czy inni (np. redaktorzy w mediach i wydawnictwach), wykorzystując swoje umiejętności zawodowe w służbie Kościołowi. Dla większości konsekrowanych parafia jest ich naturalnym środowiskiem zaangażowania. Dlatego wskazane jest, by konsekrowana była włączona w skład duszpasterskiej rady parafialnej (na temat osób powoływanych do rad parafialnych zob. Statut Parafialnej Rady Duszpasterskiej w Archidiecezji Częstochowskiej, w: Aneks do „Okólnika Kurii Metropolitalnej w Częstochowie” nr 6, lipiec-sierpień 2017) z urzędu, tak jak pracownicy parafii: reprezentant katechetów, organista i kościelny (Statut Parafialnej Rady Duszpasterskiej w Archidiecezji Częstochowskiej, nr 3.2.4). 
Ważne jest tutaj studiowanie zagadnień teologicznych, które będzie wspierało posługę słowa czy dzieła miłosierdzia ${ }^{160}$.

Posługa w Kościele często wymaga stałej formacji specjalistycznej. Niekoniecznie musi się ona odbywać w formie spotkań wyłącznie dla ordo virginum. Konsekrowane zaangażowane w posługę słowa i apostolstwo mogą uczestniczyć w formacji katechetów (szkolenia, sympozja, warsztaty), natomiast konsekrowane zaangażowane w dzieła miłosierdzia mogą uczestniczyć w formacji pracowników i wolontariuszy Caritasu.

\section{Uwagi końcowe}

Chociaż formacja w ordo virginum została zamknięta w dwóch etapach i kilku fazach, nie należy sądzić, że tematyka poruszana wcześniej nie może być powtarzana później. Dotyczy to zarówno treści odnoszących się do sakramentów wtajemniczenia chrześcijańskiego, jak i zagadnień związanych z konsekracją. Należy stale powracać wspomnieniami do dnia, w którym został przyjęty sakrament bierzmowania, jak i do dnia konsekracji. Te wydarzenia uobecnione niejako w późniejszym czasie mogą stać się źródłem ponownego wylania Ducha Świętego.

\section{ABstrakt}

Niniejsze opracowanie koncentruje się na formacji początkowej, formacji przed konsekracją i formacji permanentnej dziewic konsekrowanych żyjących w świecie, które reprezentują indywidualną formę życia konsekrowanego. Mowa jest w nim o dwóch wymiarach formacji, wynikających z charakteru stanu dziewic: chrystocentrycznym i eklezjalnym.

Wymiar chrystocentryczny dotyczy problemów związanych z nawiązaniem ścisłej relacji z Chrystusem, natomiast wymiar eklezjalny dotyczy służby Kościołowi. Obydwa wymiary związane są z działaniem Ducha Świętego, dlatego szczególną uwagę zwrócono na charyzmaty. Artykuł porusza także problematykę osób odpowiedzialnych za proces formacji, w tym szczególnie samej kandydatki czy kobiety konsekrowanej.

\footnotetext{
${ }^{160}$ Na temat studiowania teologii przez siostry zakonne zob. R. Mboshu Kongo, Wysłanie siostry zakonnej na studia nie jest strata czasu, https://www.deon.pl/religia/kosciol-i-swiat/komentarze/ art,3592,wyslanie-siostry-zakonnej-na-studia-nie-jest-stara-czasu.html (9.04.2019); B. Stypułkowska, Po co siostrom zakonnym teologia?, „Niedziela” nr 5, 1.02.2015, s. 8. Treści te dotyczą nie tylko sióstr zakonnych, ale wszystkich wiernych świeckich, w tym również konsekrowanych dziewic.
} 
Omówiono także formy wychowania odpowiednie dla dorosłych, które mogą być stosowane w formacji osób konsekrowanych oraz inne szczegółowe zagadnienia dotyczące formacji.

\section{SŁOWA KLUCZOWE}

stan dziewic, formacja przed konsekracją, formacja stała

\section{Abstract}

\section{Theological Formation in the Ordo Virginum.}

This study focuses on the initial formation, pre-consecration formation, and permanent formation of consecrated virgins living in the world who represent an individual form of consecrated life. It speaks of two dimensions of formation resulting from the nature of the state of virgins: Christocentric and ecclesial.

The Christocentric dimension concerns the problems of establishing a close relationship with Christ, while the ecclesial dimension concerns service to the Church. Both dimensions are related to the work of the Holy Spirit, therefore special attention has been given to charisms. The article also addresses the issue of those responsible for the formation process, especially the candidate or consecrated woman herself. It also deals with the forms of education suitable for adults, which can be applied in the formation of consecrated persons, and other specific issues concerning formation.

\section{KeYWORDS}

order of virgins, pre-consecration formation, permanent formation

\section{BibliografiA}

Brzegowy T., Księga Izajasza, rozdziały 1-12. Wstęp - przekład z oryginału - komentarz, Częstochowa 2010.

Cencini A., Oddech życia. Łaska formacji permanentnej, przeł. J. Zarzycka, Kraków 2004.

Chmielewski M., Cechy instytutów świeckich, www.kkis.episkopat.pl/abc-instytutow-swieckich/cechy-is (23.03.2019).

Congar Y., Prawdziwa i fałszywa reforma w Kościele, przekł. A. Ziernicki, Kraków 2001.

Deneka A., Duch Święty, w: Leksykon duchowości katolickiej, red. M. Chmielewski, Lublin-Kraków 2002, s. 223-226. 
Dockery D. S., Owoc Ducha, w: Słownik teologii św. Pawła, red. G. F. Hawthorne, R. P. Martin, D. G. Reid, red. naukowa wyd. polskiego K. Bardski, Warszawa 2010, s. 559-561.

Duchowość monastyczna dla człowieka żyjącego wświecie, http://ps-po.pl/2017/o9/o1/ duchowosc-monastyczna-dla-czlowieka-zyjacego-w-swiecie/ (1.09.2017).

Dyrektorium Służby Bożej, w: Monastyczna liturgia godzin, t. 1: Okres Adwentu. Okres Narodzenia Pańskiego, b.m.w., 1985, s. 13-45.

Fitzmyer J. A., List do Galatów, w: Katolicki komentarz biblijny, red. naukowa wyd. oryginalnego R. E. Brown, J. A. Fitzmyer, R. E. Murphy, red. naukowa wyd. polskiego W. Chrostowski, Warszawa 2001, s. 1370-1386.

Gałuszka T., Odnowa w łasce. Teologia charyzmatów św. Tomasza z Akwinu, Kraków 2018.

Giordani B., Formacja kobiet konsekrowanych. Wskazówki psychologiczno-pedagogiczne, przeł. B. Rzepka, Kraków 2007.

Giordani B., Wybrane przez Chrystusa. Kobiety konsekrowane. Studium psychologiczne, przekł. K. Kozak, Częstochowa 2004.

Grecko-polski Nowy Testament. Wydanie interlinearne z kodami gramatycznymi, tłum.

R. Popowski, M. Wojciechowski, Warszawa 1994.

Guillet J., Duch Boży, w: Słownik teologii biblijnej, red. X. Léon-Dufour, tłum. i oprac.

K. Romaniuk, Poznań 1990, s. 226-235.

Hebrajsko-polski Stary Testament. Prorocy. Przekład interlinearny z kodami gramatycznymi, transliteracją i indeksem stów hebrajskich, red. iwstęp A. Kuśmirek, Warszawa 2008. Hendry G. S., Duch Święty, w: Słownik wiedzy biblijnej, red. naukowa B. M. Metzger, M. D. Coogan, konsultacja wyd. polskiego W. Chrostowski, Warszawa 1996, s. 121-123. Jan Paweł II, Adhortacja apostolska o formacji kapłanów we współczesnym świecie Pastores dabo vobis, https://www.vatican.va/content/john-paul-ii/pl/apost_exhortations/documents/hf_jp-ii_exh_25031992_pastores-dabo-vobis.html (14.06.2021). Jan Paweł II, Adhortacja apostolska o życiu konsekrowanym i jego misji w świecie Vita consecrata, https://www.vatican.va/content/john-paul-ii/pl/apost_exhortations/ documents/hf_jp-ii_exh_25031996_vita-consecrata.html (14.06.2021).

Jan Paweł II, Posynodalna adhortacja apostolska o powołaniu i misji świeckich w Kościele i w świecie dwadzieścia lat po Soborze Watykańskim II Christifideles laici, https://www.vatican.va/content/john-paul-ii/pl/apost_exhortations/documents/ hf_jp-ii_exh_30121988_christifideles-laici.html (14.06.2021).

Jasiak R., Dary Ducha Świętego, w: Leksykon duchowości katolickiej, red. M. Chmielewski, Lublin-Kraków 2002, s. 191-193.

Katechizm Kościoła Katolickiego, Poznań 1994. 
Kiciński J. CMF, Formacja początkowa $i$ stała $w$ dziewictwie $i$ wdowieństwie konsekrowanym, www.ifzk.episkopat.pl (30.11.2018).

Kodeks prawa kanonicznego, Poznań 1983.

Konecki K., Konsekracja konsekrowanych w odnowie liturgicznej Soboru Watykańskiego II. Studium liturgiczno-teologiczne, Włocławek 1997.

Kongregacja ds. Duchowieństwa, Dyrektorium ogólne o katechizacji, Poznań 1997.

Kongregacja ds. Instytutów Życia Konsekrowanego i Stowarzyszeń Życia Apostolskiego, Ecclesiae Sponsae Imago. Instrukcja na temat ordo virginum, Pelplin 2019.

Kongregacja Instytutów Życia Konsekrowanego i Stowarzyszeń Życia Apostolskiego, Instrukcja Wskazania dotyczace formacji w instytutach zakonnych „Potissimum Institutioni”, www.zyciezakonne.pl/dokumenty/kosciol/kongregacja-instytutow-zycia-konsekrwanego-i-stowarzyszen-zycia-apostolskiego (19.03.2019).

Kudasiewicz J., Odkrywanie Ducha Świętego. Medytacje biblijne, Kielce 1998.

Küng H., Charyzmatyczna struktura Kościoła, „Concilium” 1-10 (1965/66), s. 281-293. Kupisiewicz C., Podstawy dydaktyki ogólnej, Warszawa 1995.

Lewowicki T., Indywidualizacja kształcenia. Dydaktyka różnicowa, Warszawa 1977. Lurker M., Słownik obrazów i symboli biblijnych, tłum. K. Romaniuk, Poznań 1989. Maziarz C., Proces samokształcenia, Warszawa 1966.

Mboshu R., Wysłanie siostry zakonne na studia nie jest strata czasu, https://www.deon. $\mathrm{pl} /$ religia/kosciol-i-swiat/komentarze/art,3592,wyslanie-siostry-zakonnej-na-studia-nie-jest-stara-czasu.html (9.04.2019).

Neuner P., Zulehner P. M., Zrozumieć Kościót. Eklezjologia praktyczna, przeł. A. Kalbarczyk, Poznań 2016.

O’Collins G., Farrugia E. G., Zwięzły słownik teologiczny, przekł. J. Ożóg, Kraków 1993. Ogólne wprowadzenie do Mszału rzymskiego, Rzym 2002.

Okoń W., Nowy słownik pedagogiczny, Warszawa 1996.

Okoń W., Wprowadzenie do dydaktyki ogólnej, Warszawa 1996.

Pacek S., Jak kierować samowychowaniem uczniów, Warszawa 1984.

Paige T., Duch Święty, w: Słownik teologii św. Pawła, red. G. F. Hawthorne, R. P. Martin, D. G. Reid, red. naukowa wyd. polskiego K. Bardski, Warszawa 2010, s. 159-167. Pismo Święte Starego i Nowego Testamentu w przekładzie z języków oryginalnych ze wstępem i komentarzami, oprac. zespół pod red. M. Petera (Stary Testament), M. Wolniewicza (Nowy Testament), tom 3: Stary Testament, Księga Izajasza, Księga Jeremiasza, Księga Barucha, Księga Lamentacji (Treny), Księga Ezechiela, Księga Daniela, 12 Proroków Mniejszych, Poznań 1992.

Pontyfikał Rzymski odnowiony zgodnie z postanowieniem Świętego Soboru Powszechnego Watykańskiego II wydany z upoważnienia papieża Pawła VI poprawiony 
staraniem papieża Jana Pawła II, Obrzędy konsekracji konsekrowanych. Wydanie wzorcowe, Katowice 2001.

Przygoda W., Apostolstwo osób konsekrowanych, w: Leksykon teologii pastoralnej, red. M. Fiałkowski, R. Kamiński, W. Przygoda, Lublin 2006, s. 67-70.

Przygoda W., Charytatywna funkcja Kościoła, w: Leksykon teologii pastoralnej, red. M. Fiałkowski, R. Kamiński, W. Przygoda, Lublin 2006, s. 130-138.

Rafiński G., Pawłowe pojęcie charyzmatów, w: Duch Odnowiciel, Poznań 1998, s. 300-331 (Kolekcja Communio, 12).

Rozporządzenie Ministra Edukacji Narodowej z dnia 21 czerwca 2012 r. w sprawie dopuszczania do użytku w szkole programów wychowania przedszkolnego i programów nauczania oraz dopuszczania do użytku szkolnego podręczników (Dz. U. z 2012 r., poz. 752).

Ruaro P., Lordine delle vergini. I documenti, i riti, le norme, i principia spirituals e pastorali, Torino 1990.

Ruffing J. K., Kierownictwo duchowe. Dalsze etapy, przekł. K. Gdowska, Kraków 2010.

Septuaginta. Id est Vetus Testamentum graece iuxta LXX interpreter edidit Alfred Rahlfs, Stuttgart 1979.

Siła powołania. Ożyciu konsekrowanym i poprawie relacji w Kościele. Papież Franciszek w rozmowie z Fernando Prado, Poznań 2019.

Słotwińska H., Starość wkraczaniem w ostatni etap dojrzewania do eschatologii, „Roczniki Teologiczne" 65 (2018) z. 11, s. 205-226.

Sobór Watykański II, Dekret o apostolstwie świeckich Apostolicam actuositatem, w: Sobór Watykański II, Konstytucje, dekrety, deklaracje. Tekst polski. Nowe tłumaczenie, Poznań 2002, s. 377-401.

Sobór Watykański II, Dekret o posłudze i życiu kapłanów Presbyterorum ordinis, w: Sobór Watykański II, Konstytucje, dekrety, deklaracje. Tekst polski. Nowe tłumaczenie, Poznań 2002, s. 478-508.

Sobór Watykański II, Konstytucja dogmatyczna o Kościele Lumen gentium, w: Sobór Watykański II, Konstytucje, dekrety, deklaracje. Tekst polski. Nowe tłumaczenie, Poznań 2002, s. 104-163.

Statut Parafialnej Rady Duszpasterskiej w Archidiecezji Częstochowskiej, w: Aneks do „Okólnika Kurii Metropolitalnej w Częstochowie” nr 6, lipiec-sierpień 2017.

Strong J., Grecko-polski słownik Stronga z lokalizacją słów greckich i kodami Popowskiego, Warszawa 2015.

Stypułkowska B., Biblijna katecheza o miłosierdziu skierowana do dziewic konsekrowanych. Przyczynek do formacji stałej, w: Oblicza miłosierdzia w Biblii, red. J. Jaromin, Wrocław 2016, s. 97-122. 
Stypułkowska B., Biblijna katecheza powołaniowa ze szczególnym uwzględnieniem dziewcząt, „Sosnowieckie Studia Teologiczne” 14 (2018/2019), s. 387-406.

Stypułkowska B., Formy i metody nauczania w biblijnej katechezie dorosłych, w: Katechetyk i wychowawca. Ksiega jubileuszowa dedykowana Ks. prof. Kazimierzowi Misiaszkowi SDB, Warszawa 2019, s. 141-158.

Stypułkowska B., Indywidualne formy życia konsekrowanego w kontekście Roku życia konsekrowanego, „Częstochowskie Studia Teologiczne” 43 (2015), s. 117-145.

Stypułkowska B., Maryja jako matka, siostra i nauczycielka dla dziewicy konsekrowanej, "Częstochowskie Studia Teologiczne” (w druku).

Stypułkowska B., Perspektywy dla dziewic konsekrowanych żyjących w świecie wynikające z duchowości monastycznej, „Analecta Cracoviensia” 48 (2016), s. 195-222.

Stypułkowska B., Po co siostrom zakonnym teologia?, „Niedziela” nr 5, 1.02.2015, s. 8. Stypułkowska B., Przygotowanie dorostych do posługi lektora $w$ ramach katechezy biblijnej, w: Teologiczne refleksje wokół tajemnicy wiary, red. R. Ceglarek, P. Maciaszek, Częstochowa 2020, s. 105-116.

Stypułkowska B., Pustelnicy jako przedstawiciele indywidualnej formy życia konsekrowanego, „Analecta Cracoviensia” 50 (2018), s. 125-160.

Stypułkowska B., Rady ewangeliczne w życiu dziewicy konsekrowanej, „Annales Canonici" 14 (2018) II, s. 291-321.

Stypułkowska B., Rola komentatora liturgicznego w ramach posługi słowa $i$ jego formacja biblijna, „Ruch Biblijny i Liturgiczny” 73 (2020) nr 4, s. 309-322.

Stypułkowska B., Samokształcenie kierowane w formacji biblijnej katechetów, „Polonia Sacra" 11 (29) (2007) $\mathrm{nr} 21 / 65$, s. 211-231.

Stypułkowska B., Teoretyczne i praktyczne założenia przygotowania katechetów do poprawnej interpretacji tekstów biblijnych z uwzględnieniem form samokształcenia kierowanego, Kraków 1999.

Szczepaniec S., Od konsekracji chrzcielnej do stanu życia konsekrowanego, www.konsekrowane.org/dokumenty/konferencja_konsekracja_2015.pdf (14.12.2018).

Św. Augustyn, O kazaniu Pana na Górze. Do Symplicjana o różnych problemach. Problemy ewangeliczne, tłum. S. Ryznar, J. Sulowski, wstęp i oprac. E. Stanula, Warszawa 1989, s. 21-130.

Św. Tomasz z Akwinu, Suma teologiczna, t. 11, tłum. F. W. Bednarski, London 1965.

W sercu świata. Świeccy konsekrowani, Kraków 1994.

Wątroba J., Permanentna formacja duchowa kapłanów w świetle soborowych i posoborowych dokumentów Urzędu Nauczycielskiego Kościoła (1963-1994), Częstochowa 1999. 